\title{
Strategies That Small Business Leaders Use to Motivate Millennial Employees
}

\author{
James A. Nilo \\ Wesleyan University-Philippines, Cabanatuan City, Philippines \\ Email: janilo@wesleyan.edu.ph
}

How to cite this paper: Nilo, J. A. (2021). Strategies That Small Business Leaders Use to Motivate Millennial Employees. Open Journal of Business and Management, 9, 795-837.

https://doi.org/10.4236/ojbm.2021.92042

Received: January 27, 2021

Accepted: March 27, 2021

Published: March 30, 2021

Copyright $\odot 2021$ by author(s) and Scientific Research Publishing Inc. This work is licensed under the Creative Commons Attribution International License (CC BY 4.0).

http://creativecommons.org/licenses/by/4.0/

(c) (i) Open Access

\begin{abstract}
Millennial workers occupy the majority of employment positions worldwide, which is a concern to business leaders in the United States related to having knowledge and ability to train, motivate, and retain millennial employees. Using Gilbert's behavior engineering model as a conceptual framework, this multiple case study explored the strategies that business leaders used to motivate millennial employees. The study population included 4 leaders of small restaurant businesses in eastern North Carolina, USA. Data were collected from semistructured, face-to-face interviews using 7 open-ended questions and a review of company documents, websites, and social media. Data were coded and analyzed following Morse's method of data analysis. Three themes emerged from data analysis: rewards and recognition, high-quality leader-member relationship, and professional development. The findings of this research are significant for small business leaders who want to implement effective motivational strategies to manage millennial employees to keep their organizations productive and profitable. The implications of this study for positive social change include the potential to help millennial workers grow in their careers, become financially stable, and develop into prospective leaders prepared to proper their organizations and societies in the future.
\end{abstract}

\section{Keywords}

Small Business, Employee Motivation, Business Strategies, Leadership, Millennials, Generation Y, Baby Boomers, Generation X, Behavior Engineering Model, Positive Social Change

\section{Introduction}

A historic employment turnover exists that suggests an unprecedented proportion worldwide. In 2010, baby boomers had started to retire, and by 2030 around 60 million Americans will be at the retirement age of 66 years or older (Manda, 
2015). Although generation $X$ moves up to take upper management positions, millennials are flooding the global workforce. Born between 1982 and 2000, millennials comprised 83.1 million, or about a quarter of the U.S. population, in 2015 (U.S. Census Bureau, 2015). The social, economic, political, and environmental experiences of these generations have shaped their values. Aside from experience, the employees from different generations bring with them their values, attitudes, and personal beliefs in their workplaces that define them as workers (Sanner-Stiehr \& Vandermause, 2017). It is in this light that the study of generation Y (millennials), the largest group in worldwide employment (Nolan, 2015), has become an ever-important subject. The motivation strategies toward the older generations may not necessarily work towards the youngest generation employed today. Understanding what motivates millennials is a necessary undertaking in helping businesses continue to be productive and profitable.

The departure of baby boomers from the employment sector creates challenges to industries. The baby boomers will leave skilled job positions that are difficult to fill ( $\mathrm{Ng}$ et al., 2016). Although millennials are entering the workforce in massive number, they are known to have such high expectations of their employers, and they are likely to hastily leave their jobs if employers fail to meet those expectations (Tews et al., 2015). It is a managerial challenge not only to hire the best talent, but to ensure that businesses are able to keep them employed. Without a strategy in place, businesses stand to see a high turnover among their millennial workers.

Indeed, millennials continue to be a misunderstood generation. Much of what managers know about millennials come from what the media portray them to be or through personal observations from their own children who show similar traits (Costanza \& Kinklestein, 2015). Managers hold negative stereotypes concerning their millennial employees, and they are unsure whether millennials should adjust to their workplace or the managers should adjust their leadership styles (Kilber et al., 2014). Nearly $75 \%$ of managers worry about their ability to manage and keep their millennial employees due to a new set of challenges millennials bring into the organization (Ferri-Reed, 2014a). Because millennials bring with them distinct behaviors, beliefs, and values, current management practices may not be as effective towards millennial workers. Business leaders and members of the management teams need a new strategy in managing their millennial employees, so that the employees continually show motivation to work and remain committed to their jobs. Understanding the characteristics of millennials will pave the way to understanding how to support and motivate them in their positions.

By 2030, approximately 88 million millennial employees will occupy $75 \%$ or the world's workforce, and employers continue to show frustrations, concerns, criticisms, and cynicisms towards their millennial employees' distinct attributes and behaviors compared with older workers (Kilber et al., 2014). More than $73.5 \%$ of business leaders show distress due to their inability to motivate, super- 
vise, and train their millennial employees (Ferri-Reed, 2014a). The purpose of this qualitative multiple case study was to explore strategies that small business leaders used to effectively motivate millennial employees. The target population for this study consisted of four small business leaders from restaurant businesses located in eastern North Carolina, USA who have successfully led and motivated a millennial workforce.

The structure of this research study consists of an extensive literature review on the conceptual framework used in this study followed by the background, upbringing, values, and preferences of the millennials. Next, the methodology used will be discussed to include the population and sampling, data collection process, data analysis, and the presentation of findings. Furthermore, the application of study results to professional practice will be discussed as well as the implication of this research to a positive social change. Lastly, the author laid out recommended actions for business leaders and for future researchers.

\section{Literature Review}

The conceptual framework that grounded the research for this study was based upon Gilbert's (1978) Behavior Engineering Model (BEM). Gilbert created human performance technology (HPT), and the author posited that although many business leaders correct employee behavior, improving the work environment was crucial in improving employee performance (Pershing, 2016). Through the power of observations and asking critical questions, a manager can use BEM theory towards improving human competence.

Behavior engineering deals with modifying and altering behaviors to achieve worthy performance. According to Gilbert (1978), efficient performance is only a part of BEM theory, and all managers must understand that their role is to engineer human performance by measuring competence and identifying behavioral causes. To realize efficient behavior, managers can start by fixing behavior deficiencies and by implementing a blueprint to achieve higher efficiency (Gilbert, 1978).

When employees work efficiently, they hone competence and perform in a way that meets or exceeds expectations of their jobs. In essence, Gilbert (1978) posited that workers have the knowledge, capacity and motives (called the "behavior repository") that they carry with them in their workplace necessary to do their jobs. When employees use their behavior repository supplemented by organizational support tools and stimulated by incentives, they are able to perform in a way that may yield desired accomplishments.

Gilbert (1978) discussed the management theory in BEM in which incompetence is more likely the manager's failure to define accomplishments and assign responsibilities. If this occurs, managers can troubleshoot by looking at whether the deficiency is with the environment (support tools provided by the business) or the employee's behavior. Gilbert believed that most managers summarily fix the employee's behavior rather than identify deficiencies in the workplace; providing appropriate tools including motivation incentives can easily solve per- 
formance issues.

In fact, the lack of organizational support is the cause why employees fail to achieve exemplary performance (Dean, 2016). Behavior change, supported by environmental tools, and stimulated by incentives can generate worthy performance (Gilbert, 1978). It is, therefore, wise for a manager to identify missing support factors when diagnosing performance issues in the workplace before they start addressing their employee's behavior.

\subsection{Diagnosing Performance Using BEM}

BEM is a tool used to improve performance. Gilbert (1978) explained that managers could use BEM to organize and analyze behavior as they ask the questions as listed in Table 1. As depicted in the following table, managers can use BEM to diagnose deficiencies and determine how to engineer superior performance (Gilbert, 1978). Gilbert (1978) classified BEM into six components of data, instruments, incentives, knowledge, capacity, and motives. Gilbert also numbered in sequence where a manager should look for deficiencies starting from data and ending in motives.

Gilbert (1978) formulated BEM to help managers see deficiencies in performance and improve behavior. Gilbert postulated the importance of standardizing competence, so that as the manager measures competence the employees are given proper guidance on achieving worthy performance. Gilbert based his BEM on these three constructs: 1) the measurement of competence in relation to a worthy performance, 2) the measurement of performance from typical to exemplary identifying potential for improving performance (PIP), and 3) management's measurement of performance deficiencies by uncovering deficient behavior repertory and environmental support factors. Cox et al. (2006) argued that business leaders consider BEM a leveraged solution valuable to any organization. Business leaders and members of the management teams can find value to BEM as a framework in analyzing performance issues and in applying systematic solutions without the need to rush into conclusion that employee behavior is the culprit in performance problems. Providing environmental support tools can aid employees to improve performance at the least cost to the organization.

\subsection{Iconic Moments of Millennials}

In this study of millennials, it is helpful to take a look at their history. Generation Y, or those individuals who were born from 1980 to early 2000s (Anderson et al., 2016; Hammer, 2015), witnessed several historical events growing up. Millennials confronted many challenges and these experiences forged their political and even economic values specifically with regard to their neoliberal thought processes (Wadsworth, 2017). Wadsworth (2017) argued that millennials inherited a country that promotes neoliberal economy. Millennials believe that the economic development is the center of a nation's strength (Wadsworth, 2017). Millennials believe in capitalism, and they show consumerism tendencies. 
Table 1. Sequential diagnosis of behavior deficiencies.

\begin{tabular}{|c|c|c|c|}
\hline & Information & Response & Motivation \\
\hline \multicolumn{2}{|c|}{ Environmental (1) Data } & (2) Instruments & (3) Incentives \\
\hline Support & $\begin{array}{l}\text { Do employees know how } \\
\text { well they perform based on } \\
\text { company standards? }\end{array}$ & $\begin{array}{l}\text { Do the employees have the } \\
\text { best tools for exemplary } \\
\text { performance? }\end{array}$ & $\begin{array}{l}\text { Are incentives satisfactory } \\
\text { to cause employees to } \\
\text { perform meritoriously? }\end{array}$ \\
\hline \multirow{2}{*}{$\begin{array}{l}\text { Behavior } \\
\text { Repository }\end{array}$} & (4) Knowledge & (5) Capacity & (6) Motives \\
\hline & $\begin{array}{l}\text { Do employees have all the } \\
\text { information and knowledge } \\
\text { for superior performance? }\end{array}$ & $\begin{array}{l}\text { Do employees have the } \\
\text { capability to perform } \\
\text { exemplary? }\end{array}$ & $\begin{array}{l}\text { Are employees motivated } \\
\text { to work exemplary for } \\
\text { available incentives? }\end{array}$ \\
\hline
\end{tabular}

a. As depicted under the "Information" column, employees use their knowledge (behavior repository) and data (provided by the organization) to perform at a satisfactory level (Winiecki, 2015). On the other hand, as depicted under the "Motivation" column, employees may use their set of motives (behavior repository) and incentives (provided by the organization) to perform at a level that exceeds managerial expectations (Winiecki, 2015).

Millennials grew up witnessing some momentous global events. Several significant historical events that happened as millennials were growing up helped them develop their idiosyncrasy and assumptions (Hammer, 2015). Millennials watched the fall of Enron, the Columbine High School shootings, the scandal surrounding Bill Clinton's alleged affair with Monica Lewinsky, the 9/11, and the proceeding War on Terror (Hammer, 2015). Their parents also got involved in social issues important to them. The socially-active parents of millennials passed on developmental traits while pursuing plights such as the promotion of equal rights for gays and lesbians and women's rights to choose abortion (Anderson et al., 2016). It is important to understand the upbringing of millennials to better appreciate how they think, what they value, and how they react to events around them.

Millennials take an interest in the world around them, show genuine concern for the state of their world, and volunteer to causes important to them (Wadsworth, 2017). They exercise their right to assemble and to freely express their opinions, and their participation in social causes leads to a political and social awakening (Fortin \& Hennessy, 2015). The use of social media to disseminate information and to rally support from peers and the public spring millennials into action. Their presence in many demonstrations around the country is notable.

Each generation in our world today experienced many social and political events that are different from the time of other generational cohorts. Understanding the history of each generation can help understand why each generation behaves a certain way. According to Watroba (2017), there is not an absolute rule to follow when classifying a population into different generations by the use of age ranges. What is more important is to check the shared history of each generation as common experiences during each generation's formative years shape their behaviors, values, and job approach (Watroba, 2017). Business lead- 
ers can recognize similar viewpoints and behaviors among their millennial employees because millennials grew up in a shared cultural, political, and social context.

\subsection{Helicopter Parenting}

Millennials are known to be the recipients of "over parenting" with as much as $40 \%-60 \%$ of college students confirming this experience (Kwon et al., 2016). "Helicopter parenting" means parents get overly involved with their children's affairs (Desy et al., 2017). While millennials have a strong self-entitlement due to over parenting, their generation also became the highest educated of all the generations (Desy et al., 2017). Segrin et al. (2015) identified ways parents are overly involved in their children, such as offering excessive advice, problem-solving, and expensive material gifts, mixed with interference in the child's emotional welfare. Helicopter parenting became a major force in the formative years of millennials. The incessant participation of parents allowed millennials to be academically successful.

However, there are some disadvantages of helicopter parenting. The inability of millennials to have autonomous decision-making experiences will lead to some difficulties renegotiating the parent-child relationship in adulthood (Kwon et al., 2016). Also, overly involved parenting can hinder the psychological development of a person that also compromises the ability of an individual to have a sense of control leaving them vulnerable in adulthood (Kwon et al., 2016). Several colleges and universities have acknowledged the negative effects of helicopter parenting and put policies in place to limit parental involvement. For example, Harvard University discourages parents in extending too much assistance to their children. New York Institute of Technology instructs parents to step aside to enable students to initiate decision-making activities, and Morehouse College does not allow parents to enter the campus (Earle \& LaBrie, 2016). Parents hold their children in high regard and only want the best future for them. Parents become overly involved in their children's lives, but when a child fails to meet the expectations of their parents, resentment and anger toward the parents may follow (Segrin et al., 2015). While parents of millennials may have the best intentions, being overly involved can be disadvantageous to a child. It is, therefore, important to understand how helicopter parenting shaped the upbringing of millennials.

Managers can understand that millennials lack problem-solving skills as a result of helicopter parenting (Wiedmer, 2015). Managers need to realize that their millennial employees will require more supervision and efforts towards strengthening their place in the company such as constant feedback and structure in their work (Wiedmer, 2015). Millennials appreciate constant feedback from their superiors, mentoring, and having a close relationship with their leaders (Meola, 2016). With this knowledge, managers can create opportunities for their millennial employees to improve their problem-solving skills and utilize their strengths 
in making improvements in the workplace. Through proper guidance, managers can guide their millennial workers towards success.

\subsection{Stereotypes towards Millennials}

Much of the frustrations, concerns, criticisms, and cynicism towards millennials come from negative presumptions gained by managers and supervisors from various sources. Hammer (2015) posited that the unfavorable stereotypes built surrounding millennial generation overshadowed most of the positive characteristics of millennials. Costanza and Finkelstein (2015) underscored the growing research on generational differences and how workplaces evolve in terms of job satisfaction, organizational commitment, and turnover. There has also been a steady change in personality characteristics of the workforce regarding social dominance and narcissism. Some of these stereotypes are as follows:

Self-entitled and narcissistic. Overly involved parents raised self-entitled millennial children (Desy et al., 2017). Helicopter parenting promoted and protected the self-esteem of their millennial children during their children's formative years (Costanza \& Finkelstein, 2015). Millennials believe they can achieve anything, and even though they are cognizant of their environment, they are cynical and narcissistic (Hammer, 2015; Stark \& Farner, 2015). Overly involved parents provided for all the needs and wants of their children. This type of parenting resulted in self-entitled and narcissistic traits of some millennial children.

Impatient. Generation Y children show impatience. They were born during the rapid development of technology in a post-digitized world (Kilber et al., 2014). They grew up in a wireless environment and are the main user of the social media and texting. Millennials are driven by consumerism and globalization and rely heavily on social media that they assert what they want when they want it, and how they want it (Pinzaru \& Mitan, 2016). Information gathering has become instantaneous because of technology. Millennials show impatience being dependable to technology.

Lazy. Millennials are lazy due to their self-entitlement tendencies. They suffer from a chronic delay of maturity (Orchowski, 2014). Weirich (2017) confirmed that one of the negative stereotypes for millennials is being lazy. Their parents gave into all their needs to the point that the parents became overly involved even in the emotional welfare of their children. The easy access to massive information gathered by millennials from using technology also contributed to their inability to work harder.

Stereotypes are not beneficial for organizations. Stereotypes of generations have become a business strategy that most decisions affecting employees based on their social identity generate more problems for managers (Costanza \& Finkelstein, 2015). Understanding the generational differences is essential in developing management practices so that managers can implement different leadership styles as required by different generational preferences (Berry, 2016). Un- 
derstanding millennials based on research can remove the presumptions and stigmas from business practices. In addition, understanding millennials in today's world can help business leaders and members of the management teams effectively deal with their workers.

\subsection{Characteristics of Millennials}

Misunderstanding the general characteristics of millennials and their motivational aspirations can lead to continued struggles in the workplace. Millennial employees assume majority of positions in all industries around the world, and managers tend to have a difficulty understanding them (Kilber et al., 2014). In fact, frustrated employers show concerns, criticisms, and cynicism towards their misunderstood millennial employees that hinder efficiency in the workplace (Kilber et al., 2014). Following are some of the general characteristics of millennial generation.

Socially aware. One of the characteristics of millennials is being socially aware. Even though many stereotypes millennials as cynical, they are also socially aware (Costanza \& Finkelstein, 2015). Being social aware means millennials are sensitive to the feelings and inclinations of their peers (Buzdar et al., 2016). Employees who are socially intelligent can build harmonious relationships and collaborative teams (Njoroge \& Yazdanifard, 2014). Socially aware millennial employees contribute to the greater good of their communities, do their civic duties, and volunteer to causes (Dimitriou \& Blum, 2015). Being socially aware is an important trait that millennial workers can bring to their workplaces. Their sensitivities allow them to act according to the demands of the situation.

Confident. Another characteristic of millennials is being confident. Millennials are not only team oriented, but they are also confident achievers (Carballo \& Badilla, 2014; Hammer, 2015; Phillips \& Trainor, 2014). Their belief of achieving anything in life makes millennials optimistic and practical (Dimitriou \& Blum, 2015). While millennials are competitive, as seen in their self-trust and individualistic tendencies, they can also work with others due to an upbringing that incorporated working in groups (Pinzaru et al., 2016). Confidence is another great asset millennial workers bring to their workplaces. Being confident will enable them to capitalize on their strengths and achieve great things.

Opinionated. Self-confident millennials are also opinionated, and they act in ways that seek social influence (Pinzaru \& Mitan, 2016). However, the ability to freely express one's rights, thoughts, and feelings is beneficial as it also leads to the acknowledgment of other people's rights, thoughts, and feelings (Warland et al., 2014). Understanding the importance of being able to express thoughts and feelings, managers and supervisors can help their millennial employees express feelings to take better control of behavior and in relieving built up stress to become healthy and resilient (Hewitt, 2015). Being opinionated, millennial workers can share their ideas for the benefit of their workplaces. They can also express themselves in ways that can help their team leaders understand their needs 
and desires.

Digitally connected. Millennials were born during the advent of the Internet. Because of this, millennials became digitally connected and were even sometimes referred to as the "digital natives" (Anderson et al., 2016; Pinzaru \& Mitan, 2016). Millennials have a strong desire for commercialism and globalization through their avid use of technology, and the older generations find this difficult to understand (Pinzaru \& Mitan, 2016). In fact, Villena-Alvarez (2016) argued that technology shaped millennials and their prevalent use of smartphones and other devices become a source of frustration for older generations. Millennials' lifestyle involves the constant use of technology and internet-enabled devices. Business leaders are wise to accept this fact and offer opportunities to make their millennial employees productive through the utilization of technology. The high volume of information gained from technology makes millennials well-informed.

Smart. Since millennials are the highest educated generation (Desy et al., 2017) and can access information from diverse sources, they are also smart. Millennials are not only smart, but they also think it is awesome to be smart (Belcher, 2015; Phillips \& Trainor, 2014). Technology played a role in shaping a millennial generation that has a high degree of motivation to increase understanding, improve skills, collaborate with others, and to build knowledge utilizing different strategies (Carballo \& Badilla, 2014). Millennials are smart, have the aptitude to access information, a desire to improve themselves, and the ability to work with others that make them a valuable asset to any organization. They can make a difference in any chosen endeavor.

World changers. The self-entitled and narcissistic millennials have a desire to do good. Millennials are also known as the "purpose-driven generation", and they do their part to make a difference in the world (Belcher, 2015). Millennials like to work for organizations that are socially responsible (Pinzaru \& Mitan, 2016). In fact, they believe that organizations should have a positive influence on society, and business leaders should incorporate sustainability and social responsibility into the organization's activities (Belcher, 2015). Wadsworth (2017) discussed that millennials are staunch volunteers to social causes, and they present real apprehension about the state of the world. Campione (2016) suggested that volunteer work can help millennial employees with adaptations and adjustments that can result in a positive experience in the workplace. Millennials yearn to do good deeds, and it is important for business leaders to understand this trait. Supporting volunteer efforts and involving millennial employees in corporate social responsibility programs can benefit both the organization and millennial employee.

Multitaskers. Millennials grew up in a family where they spent time doing extra-curricular activities and sports. As their parents wanted them to be successful, millennials grew up to be consummate multitaskers who are high achievers which has allowed them to be open for professional help (Rickes, 2016). Understanding this characteristic is important for business leaders because millennials 
are the highest and the best-educated generation (Desy et al., 2017; Rickes, 2016) as they acquired knowledge, honed a variety of skills, and cultivated a wide range of talents. The fresh knowledge they bring to any organization can become useful as business leaders try to remain competitive. Millennials have the drive to go the extra mile due to their tendencies to aspire to greatness.

Ambitious. The sheltered millennials are immensely ambitious about their careers and their future (Aruna \& Anitha, 2015). However, Navarro and Malvaso (2016) warned of millennials' difficulty in handling important life decisions to include career and life directions. Millennials take comfort in the guidance provided by their parents, but are often in need of professional help (Navarro \& Malvaso, 2016). Business leaders need to understand this trait, so that they are able to set out clear expectations for their millennial employees while ready and able to provide guidance when necessary.

\subsection{Learning Preferences of Millennials}

Millennials demonstrate different learning preferences. Millennials show strong confidence derived from their trust and positivism (Smith \& Nichols, 2015). It will be beneficial for organizations to cater to the needs of their millennial employees in terms of training programs tailored to their millennial employees' learning style. Some of the recommendations provided by Desy et al. (2017) were one-on-one mentorship and personalized learning plans tailored to millennials' learning styles, and collaborative, team-based learning with their peers. Organizations can also offer leadership roles fit for their confident and achievement-focused millennials that will allow them to excel in their work (Smith \& Nichols, 2015). It is, therefore, apparent that the old ways of managing and training employees may not be as effective to the younger workforce. Business leaders need to craft learning programs accordingly to address their millennial workers' preferences.

Millennials learn in different ways. They consider grades and feedback as important tools in learning as well as giving their best in their work (Phillips \& Trainor, 2014). Understanding this learning preference allows a business leader to provide constant feedback and evaluation which are useful tools in evaluating and helping their millennial employees maintain good work performance and growth in their careers (Fork \& Yeung, 2016; Pinzaru \& Mitan, 2016). Millennials appreciate receiving feedback in a timely fashion.

Experiential learning. According to Philips and Trainor (2014), teachers now understand that the traditional format in classrooms may not work well for their millennial students. Teachers are adopting techniques that allow millennial students to learn through experiential activities (Boysen et al., 2016). Experiential learning involves simulations, games, online or video-based lectures, problem-solving, and other activities (Phillips \& Trainor, 2014). Experiential learning helps millennials gain experience through hands on learning. Engagement through experiential learning allows them to engage into more active conversa- 
tions with their instructors and their peers.

Engaged learning. Since millennials are multitaskers, it is also important to consider their attention span. Engaged learning is a strategy in motivating millennial students to learn by implementing activities appropriate for their learning preparedness and readiness. For example, pre-recorded lectures are provided ahead of time with a maximum of 20 minutes so that teachers and students spend most of the classroom time with activities and discussions that engage the critical thinking skills of the students (Phillips \& Trainor, 2014). Phillips and Trainor (2014) further posited that active learning deals with creating a deep understanding of the lessons with practical implications rather than just storing the knowledge in their minds. Business leaders can adopt similar experiential and engaged learning strategies in their company training and development programs. Through engaged learning, the business leaders will continue to capture the attention of their millennial employees and promote effective learning activities.

Conventional learning. Millennials enjoyed a close partnership with their parents throughout their growing and formative years. In spite of their experiential and engaged learning preferences, Rickes (2016) argued that millennial students have conventional learning preferences. In fact, they tend to enroll in more traditional schools. Some school leaders recognize the importance of conventional learning that they have incorporated programs and events with direct participation of their millennial students' parents and families (Rickes, 2016). Millennials enjoy collaborative learning with their peers, such as doing travel studies in groups, which allows them to feel more relaxed and confident. Conventional learning, therefore, is still an effective type of instruction for millennials.

Access to technology. It is also important to recognize the integral aspect of technology in the way millennials learn and work. Millennials learn best by incorporating technology in the learning process as they associate their technological competence in relation to their ability to connect with their peers (Desy et al., 2017). Ferri-Reed (2014a) supported this idea by encouraging business leaders to tap into the technological skills of millennials as it relates to working with their coworkers. Business leaders may encourage their millennial workers to work on special projects with their older peers utilizing and integrating new technologies. Allowing access to technology, the business leaders can identify ways to make learning and working fun while accomplishing organizational goals.

Millennial employees enjoy learning with people similar to their preferences and businesses that provide avenues for them to grow. Aside from mentoring, millennials also prefer tailor-made, collaborative, and technology-based learning (Desy et al., 2017). Business leaders, therefore, should consider these learning preferences, so that they can continue to support their millennial employees. In addition, business leaders can engage their employees in higher levels of discourse and produce substantial knowledge for the benefit of their organizations. 


\subsection{Work Preferences of Millennials}

The work preferences of millennials are different from that of the other generations. These generation Y millennials have different and distinct attributes compared to older generations, and millennials are creative and technologically savvy that seek instant rewards and constant feedback (Fork \& Yeung, 2016). Access to information becomes a stepping tool for millennial workers to improve their skills.

Constant feedback. Millennials show a preference for a good relationship with their supervisors who consistently give evaluation of their employees' work. Millennials prefer to receive constant feedback from their superiors, continued coaching, close relationship with management, flexibility, individualism in the workplace, and adaptability for change (Ferri-Reed, 2014a; Meola, 2016). In fact, favorable feedback is not only preferred by millennials, but they also demand it from their supervisors (Anderson et al., 2016). Millennials grew up to a constant supervision of their parents in their lives that they also prefer constant feedback from their supervisors and easy access to information in the workplace.

Access to information and good communication. Information is a vital commodity in the workplace, and millennials prefer to work with the ability to access necessary information and communicate effectively. Millennial employees show a preference for an open and positive communication between employees and superiors and the ability to share information instantaneously with peers (Hall, 2016). The process of encouraging open communication, involving millennial employees in a decision-making process, and providing constant feedback for performance create an atmosphere of transparency welcomed by millennials (Ferri-Reed, 2014a). The ability to work effectively with access to information allows millennial employees to express their thoughts, ideas, and feelings and have a harmonious relationship with their coworkers. Millennials enjoy open communication and constant feedback because as a result, they can improve their skills.

Skills improvement. Millennial employees are confident and they are able to work effectively utilizing their strengths and abilities. They will show loyalty to an organization that allows them to improve and expand on their skills (Boysen et al., 2016). Meola (2016) further encouraged business leaders to help develop the soft skills of millennials through leadership training and communications skills enhancement. Millennial employees desire to achieve what they want when they want it (Pinzaru \& Mitan, 2016). They seek constant improvement of their skills to become better. As millennial workers constantly improve their skills, they are able to achieve greater results in the workplace.

\subsection{Work Values of Millennials}

The workplace values of millennial employees differ from their preceding generation. Kuron et al. (2015) explained that important behaviors and decision activities of millennial employees have to do with their work values. Campione 
(2015) further added that understanding millennial employees in the workplace requires an understanding of their work values and behaviors. It is, therefore, important to understand how millennials value their work and the factors that shape their career decisions. Following are some work values that business leaders should understand about their millennial workers.

Work-life balance. Millennial employees prefer a healthy work-life balance. They have the tendency to hop from one job to another if the workplace conditions are not right for them (Ferri-Reed, 2014c). Part of the work preferences includes unrestricted careers, work-life balance, and tangible rewards such are competitive pays and bonuses over intangible one (Ertas, 2015). Compared to the preceding generation, millennial employees prize work-life balance more and consider money as their top priority (Anderson et al., 2016). In fact, the inability to spend sufficient time with personal obligations and pursuits as much as spending sufficient time with work can be a cause of dissatisfaction for millennial employees (Nolan, 2015). It is, therefore, important to note that heavy workloads can compromise personal aspects of millennial workers' lives. Consequently, this may have a detrimental effect on their motivation on their jobs. Millennials value having personal time off away from work.

Actively involved parents raised family-centric millennials, which made their children more focused on their private lives than on their careers. Having time with their families is valuable for millennials, therefore, they desire a work-life balance (Chen \& Lian, 2015; Smith \& Nichols, 2015). In fact, millennials measure success through the quality of life that they have (Hammer, 2015). Without work-life balance, millennial employees are more likely to change jobs and employers than the older workers (Ertas, 2015; Hammer, 2015). It is, therefore, vital to understand how managers support the work-life balance demands of their millennial employees to help prevent turnover. The changing preferences of the workforce may force business leaders to rethink the way they conduct business and implement ways to promote and protect the quality of life of their employees.

Individualism. Millennial employees prefer work pursuits that are geared toward helping them achieve their best potentials and value individual workplace contributions. Millennials are more likely to show individualistic traits of self-esteem and determination than the older generation (Campione, 2016). These younger employees value opportunities to self-actualize in their jobs which includes self-growth and in achieving personal interests (Chen \& Lian, 2015). The individualistic tendencies mean millennial employees value their ability to contribute and their feeling of involvement in their work (Anderson et al., 2016). Millennials were raised as trophy kids, desire to pursue the things that they want, and they believe in their abilities. Employers and managers need to support the individualistic behaviors of their millennial employees and offer opportunities for personal growth.

Recognition and involvement. While millennial employees excel in individua- 
listic endeavors, they also yearn for involvement and recognition. Millennial employees are attracted to organizations that promote employee recognition and involvement (Catano \& Hines, 2016). Being involved means the employers accord millennial employees the opportunities to participate in decision-making activities especially when the issues affect them (Dimitriou \& Blum, 2015). Also, millennials expect rewards and recognition for their accomplishments (Pinzaru \& Mitan, 2016). Managing millennial employees requires creating an environment of respect, recognition, fairness, growth, and encourages involvement (Fork \& Yeung, 2016). Goal-oriented millennial employees achieve great things for themselves and their organizations. It is, therefore, essential for business leaders to recognize the contributions of their millennial workforce and to keep them involved in their jobs.

\subsection{Leadership Support and Influence}

Business leaders and management teams have a very important role to play to help their millennial employees thrive in their careers. Desy et al. (2017) believed in the importance of building a bridge between millennials and their leadership team as well as with their peers of older generations. Hall (2016) also observed that the need for millennial employees to have a close relationship with their team leaders comes from their similar relationship with their parents. Business leaders and management teams are the persons in authority whom millennial employees can count on for influence and guidance. It is, therefore, a vital training program to arm the business leaders and management teams with the understanding of their millennial employees' characteristics, tendencies, learning preferences, and work values. The business leaders and management teams can further provide support and influence through several aspects of employment.

Preventing job burnout. The type of support and relationship millennial employees have with their team leaders can influence their success in their jobs. In fact, Jiang and Yang (2016) highlighted the need for the compatibility between the management style and the employees' psychological characteristics to relieve job burnout of the employees especially with millennials. Job burnout can cause employees to have health issues such as the feeling of weariness after an exhaustive use of energy, apathy and indifference from the task ahead, and to believe that they are incompetent (Tong et al., 2015). There is an academic and general interest in job burnout among generation Y millennials despite limited research (Jiang \& Yang, 2016). Unless academicians do more empirical studies on job burnout among millennials, and business leaders establish proactive measures to help alleviate stress among their millennial employees, it is very likely that the rate of suicides among millennials will continue to go unabated.

As job burnout and its consequences are a reality in today's workforce, business leaders and management teams need to further address this to alleviate stresses and health concerns of their millennial employees. Jiang and Yang 
(2016) examined millennials in China and discovered that work overload and work ambiguity add to job burnout while leadership support, co-worker support, and job autonomy may prevent job burnout. Organizational leaders must get to know their employees' burnout experiences and mental processes to be able to respond and intercede effectively (Tong et al., 2015). Leadership support, harmonious workplace relationships, and the ability to work independently can lead to a higher chance of assuaging job burnout. Appropriate and timely intervention can also help millennial employees succeed in their positions.

Personalized job motivation. Small business leaders can use the knowledge of the characteristics, values, and tendencies of their millennial employees to motivate them. Hammer (2015) discussed that millennial employees who like to get things done and have a close relationship with their superiors could flourish in their careers as a motivated workforce. Campione (2015) explained that the need for a more personalized feeling within an organization is evident as millennial employees' preferences. Furthermore, millennials, according to Campione (2015), prefer smaller firms because they can get closer supervision, attention and more personalized feedback, and career development guidance compared to being employed in a larger organization. Millennial workers desire a connection with their managers and supervisors, and they, in fact, want their team leaders to be their coaches or mentors (Gilley et al., 2015; Meola, 2016). It is then necessary for business leaders and members of management teams to understand that motivating their millennial workforce may require a more individualized approach. As millennial employees receive personalized attention and feedback, they thrive in their positions.

Extrinsic over intrinsic motivation. There are two types of motivators: intrinsic and extrinsic. Intrinsic motivators are rewards that come from within such as achievement and development, while extrinsic motivators are external rewards like bonuses or promotions (Singh, 2016). Ertas (2015) argued that millennial employees prefer extrinsic over intrinsic rewards. Chen and Lian (2015) supported the idea that millennial workers prefer extrinsic rewards such as money to support their lifestyle and work-life balance preference. Lin et al. (2015) tested the relationship between utilitarian (extrinsic) motivators and job performance in a Chinese context. Lin et al. (2015) discovered that millennial employees who prefer extrinsic motivators perform better in in-role performance to maximize direct benefits (salary increase or bonuses) as well as in extra-role performance to achieve more significant indirect benefits (improved standing in the workplace or competitiveness for promotion). Business leaders can learn from this concept so that they can further support the utilitarian or extrinsic motivation preferences of their results-oriented millennial workers. Millennials can perform well in their positions if given the rewards that may mean more to them.

Job autonomy. Millennial employees also value job autonomy. While millennial workers value a closer relationship with their superiors and cherish receiving constant feedback from their team leaders, they still prefer working with 
some aspects of autonomy in their job. Henstra and McGowan (2016) explained that millennial employees have less interest in intrinsic motivation and prefer a healthy work-life balance including autonomy from supervision. Job autonomy is the ability to decide, determine the goals, plan, schedule, and implement independently (Jiang \& Yang, 2016). However, Park (2016) warned that job autonomy might not have the same employee outcomes for all organizations. There is still a gap in literature as to the effects of job autonomy to individual employee outcomes in relation to a business strategy context. Business leaders should carefully understand a healthy balance between constant feedback and supervision and job autonomy.

With job autonomy, millennial employees can take ownership of their work. As millennial employees like to get involved in their organization and contribute to decision-making activities (Catano \& Hines, 2016; Dimitriou \& Blum, 2015), job autonomy, according to Park (2016), is how business leaders value the work and contributions of their employees towards organizational goals. Millennial workers do not take responsibilities lightly. They value increased responsibilities with job autonomy and the ability to tackle challenges to get things done (Jiang \& Yang, 2016). One of the reasons millennial employees succeed is if they have autonomy in their jobs and can work independently to utilize their skills.

There are some emotional and psychological considerations as to why employees prefer job autonomy. For example, there is a correlation between the absence of job autonomy and the feeling of work pressure in some individuals, or the inability to achieve job objectives when there is lack of job autonomy for millennial employees (Jiang \& Yang, 2016). If employees have the autonomy to decide on how they complete their work and gain support for their decisions, they can produce more innovative ideas (Woods, 2016). Sometimes, employees experience hierarchical plateau, or face dim prospect of promotion in their current workplace. Managers can help their employees re-identify work fitness by granting job autonomy (Xie et al., 2016). Job autonomy reduces stress, and when employees perform autonomously, they are also able to trust their organization more (Cho \& Song, 2017). Job autonomy can have significant emotional positive effects on millennial employees. Business leaders should seek to understand the job autonomy preference of their employees to help them prosper in their jobs.

On the other hand, job autonomy may also become a hindrance to success. Gov (2015) argued that empowering and giving job autonomy to employees might even give them a sense of competence that may result in lowered pay satisfaction. Since job autonomy is an intrinsic motivator and millennials prefer extrinsic rewards, job autonomy may not be as effective to some millennial employees. Singh (2016) recommended understanding the job autonomy preferences of the employees and providing them the leeway to decide on their work without micromanagement from their superiors, but with clear accountability. Millennial employees can utilize their skills and their ability to work independently. However, business leaders and management teams must also communi- 
cate work expectations and hold their millennial employees accountable.

Job satisfaction. Aside from job motivation, it is also important to ensure job satisfaction of millennial employees. Recruiting the best talents in the market is not the end of a hiring manager's job. Job satisfaction is the employees' overall assessment of their workplace, how they feel about their jobs, and, upon weighing alternatives, they arrive at a conclusion of the quality of their employments (Campione, 2015). Millennial workforce has specific expectations of their jobs and their workplace, including placing an importance on their ability to improve their skills, work on challenging tasks, and opportunities for promotions (Boysen et al., 2016). Boysen et al. (2016) explained that if businesses fail to meet these expectations millennial employees may leave their jobs. In essence, upon evaluating their job situation, millennial employee decides on whether to continue being employed in their current workplace or to look for a job elsewhere. Job satisfaction, therefore, is related to job retention.

There are several ways to support job satisfaction of millennial workforce. Supervisors that provide constant feedback support job satisfaction and employment longevity (Hammer, 2015). Work values influence the job satisfaction of the employees (Kuron et al., 2015). Millennials also look for good communication between their peers and their leadership teams as an indicator of job satisfaction in the workplace (Hall, 2016). Millennial workers enjoy infusing fun in the workplace as a predictor of job satisfaction, which includes fun job activities, leaders promoting a fun workplace, and coworker socialization (Tews et al., 2015). Smith and Nichols (2015) explained that since millennial employee strives to overachieve, they value mentoring and opportunities to enhance their jobs and, as a result, increases their job satisfaction. Business leaders and members of the management teams need to understand the distinct job satisfaction of their millennial employees. Through relationship building and open communication, they can glean valuable information and help support their millennial employees in their job assessment towards a satisfactory conclusion.

Job satisfaction is different for the different generational cohorts in the workplace today. Understanding the job satisfaction of the diverse workforce requires particular and distinctive managerial attention and knowledge to support the various working styles of each generation of employees (Lewis \& Wescott, 2017). Lewis and Wescott (2017) added as it relates to job satisfaction, it is essential for managers and business leaders to create dynamic, collaborative teams through the recognition of organizational skills diversity resulting in increased production, work proficiency, and job satisfaction. The work culture and values of the older generation may not fit with the values of millennials. For example, one way to create a dynamic, virtual collaborative cross-generation team is to encourage each generation of employees to utilize their strengths in helping solve intricate business problems (Ferri-Reed, 2014b). In case of millennial employees, business leaders can provide the technological hardware to allow them to perform well and enjoy their work. Business leaders may bring their or- 
ganizations forward by using the diversity of talents and by supporting the job satisfaction of all generational cohorts in the workplace.

Job retention. To retain their best talent and prevent costly employee turnovers, it is an essential task of employers to support job retention. Aruna and Anitha (2015) posited that the generation $Y$ employees value six job retention enablers that include mentoring, career advancement, job satisfaction, involvement, work environment, and nature of work. Researchers have long recommended several job retention strategies such as improving training and development programs, increasing compensation, and providing career development paths, but business leaders can also use several job motivation strategies useful for managing millennial employees such as work engagement and extrinsic rewards (Deery \& Jago, 2015). Management teams can initiate conversations with their millennial employees, and craft policies that can help increase retention rates since the needs of each employee may vary from their peers. Managers and supervisors have the ultimate task of job retention.

Business leaders and members of the management teams can create a work climate that can support job retention. According to Thompson and Gregory (2012), millennial employees leave their managers, not their jobs, if they are not happy. Therefore, the kind of leadership support and relationship can determine the job motivation and retention for the generation Y workers (Thompson \& Gregory, 2012). Leadership styles used towards the older generations may not be as effective when used towards millennial employees, so Nolan (2015) suggested customizing leadership strategies to meet the demands of their millennial employees when it comes to job retention. Some leadership supports needed to help retain millennial workers include looking past the common negative stereotypes and assisting them with their career development goals, creating a work environment that fosters meaningful and trustful peer interaction, and endorsing job autonomy (Nolan, 2015). Establishing and maintaining a healthy relationship with generation $\mathrm{Y}$ employees is a key to successfully leading an organization. Job motivation and job satisfaction both have a goal of retaining employees.

\subsection{Millennials and Their Organizational Commitment}

The volatility of job retention for millennial workers due to their misunderstood workplace values and learning preferences is a sign for an overall assessment of ways to keeping them employed for a long time. Breaking down barriers brought about by negative stereotypes towards them, resolving management frustrations, concerns, and cynicism, and adjusting management styles can help lead millennial workers to be successful in their positions, keep them employed for a long time, and can affect their commitment to their organizations. Smith and Nichols (2015) underscored the importance of learning more about job satisfaction and organizational commitment of the employees especially since millennials have come to meld with the older generations in the workplace. Also, managers must understand what satisfies and motivates millennial employees to attract the best 
talents and keep them employed (Smith \& Nichols, 2015). If employees have a strong commitment to their organizations, they go above and beyond the expectations of their performance description (Anggraeni et al., 2017). Organizational commitment in essence is a psychological contract between the employer and the employee where personal and organizational values create results that inspire mutual trust. For example, millennial employee who seeks continual meaning and a sense of purpose in their jobs also wants their organizations to behave in a socially responsible manner (Martin \& Ottemann, 2015). Business leaders can seek to understand the work and personal values of their millennial employees to learn how to lead them positively and effectively. When millennial employees show commitment to their organizations, they also stay employed for a long term.

In a study whether organizational commitment across generational cohorts has to do with age or education, Jones (2015) discovered that there were no differences in organizational commitment among nurses from various generations (age), but nurses with different qualifications (education) demonstrated varying levels of organizational commitment. For example, baby boomers with bachelor's and master's degrees in nursing showed the highest levels of organizational commitment. Jones (2015), however, also noticed that work preferences varied from different generations with millennials working smarter rather than harder, placing importance on work-life balance, and they utilize their technical skills and best practices that benefit the organization. Due to differences in organizational commitment across generations, it is vital for business leaders and members of the management teams to understand the various needs of their employees and support their distinct expectations to remain committed in their jobs and their places of work.

\subsection{Unleashing the Best Potential of Millennial Workers}

Meeting millennials where they are and realizing their preferences and tendencies are crucial to unleashing their best potential. The negative stereotype of millennials will not help an organization; tapping on the best qualities of millennial workforce can help teams succeed. Business leaders need to take into consideration the psychological factors affecting the motivation of workers, their productivity, work autonomy, social concerns, and interpersonal relationships in the workplace as these can drive productivity for the organization (Singh, 2016). Furthermore, business leaders need to understand the hierarchy of motivations of their employees and the degree to which an employee values each aspect of their job-from the basic units of safety and belongingness to higher degrees of self-esteem and self-actualization (Maslow, 1943). Lastly, business leaders and management teams need to understand the generational differences, dynamics at play, and to foster effective communication and collaboration among members of different generations to improve company performance (Njoroge \& Yazdanifard, 2014). Since different generations have different shared values, motivating 
employees also require strategic steps to ensure efficiency while finding that common core that everyone can share together since employees, regardless of generations they belong to, are motivated by reasonably similar things in the workplace (Njoroge \& Yazdanifard, 2014). By understanding the unique traits, preferences, and values of millennial worker, business leaders can implement motivation programs and create work environment that are effective in bringing out the best in each employee.

In summary, it will be beneficial for business leaders and managers to understand the history, upbringing, and values of the millennial generation as well as their work values and learning preferences. Stereotypes do not only inaccurately portray the millennials but hurt their abilities to be recognized from their true worth and contributions to their workplaces and the world they live in. Organizations stand to benefit from a generation that is ready to make a difference.

\section{Methodology}

The purpose in this qualitative multiple case study was to explore strategies that small business leaders use to motivate millennial employees effectively. The target population for this study consisted of four small business leaders from restaurant businesses located in eastern North Carolina who have successfully led and motivated a millennial workforce. The implications for positive social change included the potential to promote understanding of the characteristics, values, and preferences of millennials that may eliminate negative perceptions towards them. Fostering acceptance and knowledge of millennials, business leaders and community members can provide opportunities for millennials to achieve their highest potential and allow them to make a positive difference in the world.

The central research question of this study was the following: What strategies do small business leaders use to motivate millennial employees?

The interview questions reflect the central research question. Each interview question was crafted in a way that addressed the research question. The design principle used in writing the interview questions is standardized open-ended interviews. This follows a structure in the wordings of the questions so that all interview participants receive the same set of questions but their responses are open-ended to allow them to provide as many details as possible (Turner, 2010).

1) What strategies do you use to motivate your millennial employees?

2) What, if any, training opportunities or resources does your organization provide to help you motivate a millennial workforce?

3) How did your millennial employees respond to your various motivation techniques?

4) How do you determine the effectiveness of implemented strategies to motivate millennial employees?

5) What were the key challenges you faced in motivating a millennial workforce? 
6) How did you overcome those key challenges?

7) What other information regarding motivating millennial employees can you provide that we have not already discussed?

\subsection{Population and Sampling}

A population is a group of individuals who share common characteristics and identifying the population at the early stage of research is crucial (Asiamah et al., 2017). Selecting a sample population should mirror homogeneity present among the participants (Alase, 2017). The population in this multiple case study included small business leaders in restaurant businesses located in eastern North Carolina who met the participant criteria. Purposeful sampling was employed for this research study. Researchers use purposeful sampling for most research studies that are not meant to be exhaustive as if they can gather enough data to answer their primary research question (Benoot et al., 2016). Through purposeful sampling, a researcher identifies a population that can provide ample information for a comprehensive study (Gentles et al., 2015; Van Rijnsoever, 2017) as well as selects individuals or groups that can best share knowledge and experience about a case or a phenomenon (Palinkas et al., 2015). An individual with the knowledge and experience in using effective strategies to motivate millennial workers can help address the central research question. Identifying the study population is a step a researcher needs to take to determine the sample size required.

Four participants were selected in this study to gather in-depth data. A qualitative researcher's goal is to gain an understanding from participants who can share an in-depth knowledge with regard to the research questions (Asiamah et al., 2017). Qualitative researchers use smaller sample sizes and ensure data saturation (Gentles et al., 2015). Data saturation is the determining factor in the adequacy of qualitative sample size. The fourth participant did not provide new information which indicated that data saturation has been achieved.

A researcher narrows down the target population by establishing participation criteria. A researcher selects fewer interviewees who are accessible and can provide detailed information on a research topic (Asiamah et al., 2017). A researcher determines the criteria for selecting participants such as tenure, gender, or type of business (Anderson, 2010). To be eligible for this study, the participants must meet the following criteria: a minimum of 2-year fulltime small business leadership experience, at least three millennial subordinates, and implemented successful strategies that they are using to motivate millennial employees. The criteria were appropriate to ensure richness in information contingent with the goal of exploring strategies that small business leaders use to motivate a millennial workforce effectively.

\subsection{Data Collection}

A researcher identifies the instruments needed in collecting data. In qualitative 
research, the researcher is the primary data collection instrument (Orange, 2016). Other data collection process includes interviews, focus groups, observing, and review of company records (Rimando et al., 2015). Aside from interviews, a researcher may also collect data from written reports and other formats to gather information from the participants (Willgens et al., 2016). Semistructured interviews were used in collecting data for this study. To conduct triangulation of data, review of company records was done including company websites and social media.

Each interview question was crafted in a way that addressed the research question. Qualitative researchers most commonly use the interview in collecting data (Wilson et al., 2016). To maintain the quality of data collected, a researcher implements data collection protocol (Castillo-Montoya, 2016). A researcher may also include essential items in data collection protocol such as plans on catering to the scheduling needs of the participants, listing the interview questions, and making observation notes during interviews (Yin, 2014).

To enhance reliability and validity of data collection, member checking was used. Member checking is a way to improve the reliability and validity of data collection instrument (Hadi \& Closs, 2016). A researcher uses member checking by providing a transcript of the interview to the participants to ensure that the researcher represents the participants and their concepts accurately (Simpson \& Quigley, 2016). Furthermore, a researcher conducts member checking to ensure accuracy and credibility of the data collection process (Boswell et al., 2015). Therefore, after each interview, the participants had the chance to review the researcher's notes and make changes to their answers to the interview questions before leaving the meeting.

\subsection{Data Analysis}

Data triangulation of data sources was an appropriate data analysis process for this case study. A researcher uses data triangulation to analyze data from more than one source of evidence (Yin, 2014). According to Fusch and Ness (2015), data triangulation improves the accuracy of study findings. Ang et al. (2016) discussed that researchers maintain credibility and achieve trustworthiness in their work through triangulation of multiple data sources. The data were analyzed from semistructured interviews and from a review of company records such as training and curriculum the company uses relating to motivating millennial employees, performance improvement plans, coaching/mentoring notes, measured key deliverables showing successes, management assessments, and documented customer feedback. The recorded observations as notated in the interview protocol were also analyzed.

Morse's (1994) stages of data analysis were used, which are 1) comprehending, 2) synthesizing, 3) theorizing, and 4) recontextualizing. The comprehension stage started as soon as data gathering began. Comprehending involves gathering data through interviews a researcher will use to describe and write a research 
study (Morse, 1994). After conducting semistructured interviews, TranscribeMe third-party transcription service was used to convert recorded interviews into written texts. A signed confidentiality agreement was secured from the vendor and the transcript was reviewed for accuracy.

The utilization of technology in data collection and analysis was appropriate. A researcher may utilize any computer-assisted qualitative data analysis software (CAQDAS) in handling, managing, and manipulating large amounts of data (Houghton et al., 2015). The transcript was transferred into NVivo qualitative data analysis software and used the tool to help with the assignment of codes and the analysis of data. A researcher may identify codes that emerge from the data (Willgens et al., 2016). Cho and Lee (2014) explained that through coding, a researcher could establish the manifest as well as underlying meanings of texts. Morse (1994) demonstrated that a researcher might use NVivo to unearth concepts and to expose thoughts within the texts. NVivo qualitative data analysis software was utilized in coding data and generating themes. However, the actual analysis of data depended on the researcher's skills as NVivo was only a tool that aids a researcher.

The second stage in data analysis was synthesizing which involved synthesizing the data and organizing it so that a researcher could code the data appropriately. A researcher synthesizes the coded data by looking for patterns and creating memos from those patterns (Miles \& Huberman, 1994; Morse, 1994). Miles and Huberman (1994) explained that the memos are summary statements of each code that a researcher uses to understand each data better. A qualitative researcher organizes the codes into nodes or themes and analyzes these themes as they emerge (Harif \& Hoe, 2018; Houghton et al., 2015). Themes that developed from analyzing the codes were identified. The nodes that arose were organized to check how these nodes or themes answered the research question.

After identifying themes, the third stage is theorizing the data. Theorizing involved a comprehensive appraisal of the data (Morse, 1994) and an assessment of the relationships among the data (Houghton et al., 2015). Relationships among these themes were analyzed as well as their meanings. The themes were crosschecked with the literature review to demonstrate correlation with Gilbert's BEM, the conceptual framework of this study. The themes from participant responses were ensured that addressed the following central research question: What strategies do small business leaders use to motivate millennial employees? I asked the study participants to bring company records that contain information on strategies to motivate millennial employees successfully.

When no new themes emerged, data saturation was attained. A qualitative researcher meets data saturation when no new concepts or ideas arise (Hancock et al., 2016). Data triangulation does not only enhance the validity of the study but helps achieve data saturation (Fusch \& Ness, 2015). The data collected from the semistructured interviews and review of company records as well as interview notes were triangulated to look for common themes, to boost the reliability of 
the study, and to help achieve data saturation. The fourth stage of data analysis involved recontextualizing the data, which included the development and presentation of study findings (Morse, 1994).

\section{Presentation of the Findings}

The overarching research question for this study is the following: What strategies do small business leaders use to motivate millennial employees? Three themes emerged from the data analysis: 1) rewards and recognition, 2) high-quality leader-member relationship, and 3) professional development.

\subsection{Rewards and Recognition}

The business leaders who participated in this study agree that one of the prime motivators for their millennial employees is rewards and recognition. In the analysis of data, two subthemes emerged: 1) compliments and 2) incentives. Compliments include verbal praises and written reviews while incentives include tips millennial employees receive from their customers and bonuses they receive from their company for meeting certain goals.

Compliments. Business leaders indicated that compliments are important in keeping their millennial employees motivated. Participant 1 said, "You have to use-and also to motivate them - pretty much, basically, always be grateful and thankful for them, and let them know they are doing a great job, and compliment them." Participant 3 agreed by saying, "I praise them when they're doing really good things." Whether an employee does an exceptional job or learns from a mistake, business leaders who give verbal compliments keep millennial employees motivated. According to Participant 4, "I just make sure that they are on the same level as me. I congratulate them. And when they make a mistake, I help correct them. And, then they get it right, we high five, and we keep it moving."

Customer reviews through websites and social media are also a way for business leaders to relay compliments from customers to their millennial employees. However, customers do not always include the names of the employees in their reviews. Participant 2 explained, "You get Google reviews, you get the Yelp reviews or complaints, but it doesn't say said person. It says 'This business did this." Participant 1 added, "If customers are leaving reviews either on TripAdvisor or any of those websites that provide that review information and, then, they mention the name... and, then, they provide their [server's] name like, 'Oh, such employee give me awesome service"' it would be helpful in complimenting their employee. Both praises and corrections are necessary tools in ensuring millennial employees' success in their jobs. Anderson et al. (2016) posited that managers need to have a balance in complimenting and correcting their millennial employees. An effective approach in praise and correction will help millennial employees understand how managers value their work and the ways millennial employees can always improve. 
Incentives. Participants 1 and 2 both reported incentives as part of their motivational strategies. When asked about the effectiveness of implemented strategies in motivating millennial employees, Participant 1 replied, "Well, basically, here it's really easy because you do it on-I base it on, for example, the tips they get. And that's the best way, just on tips and basically reviews." Participant 2 also explained, "We have incentives. We have weekly prizes. And, so those incentives and those weekly prizes normally keep my whole crew motivated to what I need them to do." Participant 2 delved deeper on the incentive program and how this strategy helps prevent absences among millennial employees:

"And, then, the things that I do is, again, based off the incentives We have this thing, hours. So, the more peak hours you work, the more incentive points you receive. So, a lot of my employees don't like to call out for the peak time. Oh, they love it. They love it because my incentives are good. So they love it. The computer automatically sets goals. And, so, if they reach their goals, I let them fix their own food of their choice. So, they love the techniques that we use here. They're motivational techniques because they know what they need to get done."

According to Participant 2, it was the first time during our interview in many months that an employee missed work during peak hours except during the hurricane event. The incentive program seems to be working for Participant 2's team. Participant 2 also explained the add-ons incentive:

"We have a real integrated system. And, the system spits out goals and objectives daily, weekly, and monthly. And, basically, that way I know if it's reaching them if we reach those goals... Everything is based on add-ons. So, if a large pie is $\$ 10$, you want to do some type of add-on... When I first bought this business, there were no incentives. There were no add-ons. Now, we have incentives for cleaning time, box folding time. So, all of the challenges were overcome by the incentive packages that we put in. They have a system in place where they don't have that error."

According to Participant 2, through incentives, not only would millennial employees get the job done, but they would get the job done in a shorter period of time without any mistake. As millennial employees do their tasks more efficiently, they are also helping increase business sales by upselling products through the add-ons. In return, millennial employees get incentives from the restaurant which they really love.

The participants confirm the review of the professional literature as well as Gilbert's (1978) BEM, the conceptual framework of this study. Gilbert (1978) argued that managers can enhance human competence by improving organizational support factors including incentives. Managers need to ensure that incentives are satisfactory to allow employees to perform well. Millennial employees prefer extrinsic (or tangible) rewards over intrinsic (or intangible) rewards (Ertas, 2015; Singh, 2016). Millennial employees like monetary rewards in order to support their lifestyle (Chen \& Lian, 2015). On the other hand, George and Wallio (2017) argued that while millennial workers place a high importance on ex- 
trinsic rewards, they also find it difficult to accept corrections. Catano and Hines (2016) added that millennials thrive in an organization that recognizes employees. Verbal praises, customer reviews, and tangible incentives are effective strategies in keeping millennial employees motivated. It is important for business leaders to find ways to compliment their millennial employees, correct them in a manner that promotes learning, and provide incentive programs tied with individual and company goals to keep their millennial workers motivated while increasing productivity and profitability.

\subsection{High-Quality Leader-Member Relationship}

All participants reported effective leadership through a high-quality leader-member relationship as another strategy in motivating their millennial employees. Millennials have different attitudes and behaviors compared to their older coworkers. The small business leaders agreed that they need a different management style when dealing with their millennial employees. Participant 2 believed "Millennials are special. They're a different group." Participant 4 added, "Learn your employees." Participant 1 explained "Well, this is very important-the way you approach them because that's the... basically, to start building your structure. Does that make sense? So, it's got to be very important the way you approach them." There are four subthemes that emerged under high quality leader-member relationship theme: 1) respect, 2) trust, 3) support, and 4) right balance.

Respect. The participants expressed that a respectful relationship can help motivate their millennial employees. Participant 4 underscored that millennial employees do not do well with authority:

"It's kind of hard just because you're not allowed to be yourself. You can't have the same attitude that you would with somebody just outside of work... And, that takes a lot for some people especially when you have those that like to talk back, or tell you what they're going to do, and how they're going to do it. Those cause problems."

In order to overcome this challenge, Participant 4 suggested to find a different approach in dealing with millennial employees. "And, just the way you talk to them," Participant 4 added. "That's the big thing. A lot of them, they want you to be more friend-like versus a boss." Participant 3 agreed with Participant 4, and uses the Golden Rule:

"I treat them like humans. I treat everybody equal to me. I don't treat them as employees where I'm the manager, so I'm above them. And, to me, that's the biggest thing. It's treating them exactly like I want to be treated by other people. The Golden Rule, basically."

Participant 3 further explained that millennial employees respond to their leaders a whole lot better when treated with respect. "Whether it's something they enjoy or not, they, at least, respond to it with respect," said Participant 3. "And, just because I'm their manager doesn't mean they have to jump down and 
respect me right away. I have to give them a reason to want to respect me," Participant 3 added.

Trust. A trusting leader-millennial employee relationship is another strategy the business leaders disclosed. According to Participant 1, providing training alone is not sufficient. "Train them to where you can trust them so you can execute your strategies," Participant 1 said highlighting the benefits of a trustful relationship to business. Participant 2 capitalizes on the strengths each millennial employee provides without micromanagement. "If you say you have experience running the POS system after your first hour here, I'll just tell them to leave you alone for a few minutes to see how you actually focus and handle the situation," explained Participant 2.

Participant 3 stated that a manager, too, can benefit from a trusting relationship with their millennial employees. "I know I have a lot of feedback when they move me from store to store. I have a lot of employees get very upset that I'm leaving," Participant 3 explained. Participant 3 added that when employees trust their leader, "people seem to enjoy coming to work and wanting to fill shifts in and things like that."

Participant 4 agreed that millennial employees tend to be more open when the relationship is on a friendship level. "If they consider you a friend or you talk to them on a friendship level, they're more likely to take in what you're telling them versus you're just talking to them on a boss level." According to Participant 4, "Just telling them what to do versus asking them to do something, or just little things like that make it a lot easier approach to the ones that don't really do well with authority."

Support. The participants also noted that leadership support helps in motivating millennial employees. Participant 1 said, "I help them if they need help with anything. That keeps them motivated to know that if they still don't know everything, they still have a chance to ask more questions." The leadership support strategy is vital especially since business leaders deal with human beings with different types of needs. "They also have a personal life, correct?" Participant 1 pointed.

It is vital for business leaders to get to know their millennial employees. Being able to anticipate and address their millennial employees' needs can help the business leader address any issues with staffing to prevent disruption of restaurant services. Participant 1 explained that it is unavoidable for employees to bring their personal life into their workplace:

"But, at the end, you still are a person. When they come in the door, you have to get to know your employees more to know their needs. As an employer, you have to make sure that your employees... that you get to know their needs as well like, oh, hey, this lady has three kids such and such and then you're prepared also in case something happens. You know that three of your four employees have kids, something is going to happen there."

Participant 1 understood the importance of anticipating problems before they 
occur. By getting to know millennial employees and their needs, business leaders can change plans to meet the demands of the business based on available staffing. At the same time, millennial employees appreciate their team leaders for providing leadership support.

Participant 3 believed that when millennial employees trust their leaders, they are more open about their situations, and the leaders are able to provide support when needed. "They're not afraid to come to me when they have a problem. They're not afraid to come to me if they feel something was unfair," Participant 3 expressed. Participant 3 added, "They're not afraid to come to me because they know I'm going to listen to what they're telling me and kind of take it into consideration." Participant 4 had similar thoughts, "To know your employees, it helps it go a lot better especially when you can tell when they're going through something by just the way that they're working." Participant 4 pays attention to millennial employees' work ethics, "Their work ethics drop when they're going through something. Just kind of be there for them. Have an open relationship with them."

Right balance. The business leaders also pointed out that while having a trustful, supportive relationship towards millennial employees helps, it is also important to keep a right balance on the leader-member relationship. Participant 1 called this the structure that does not frequently change, "If they have a structure, have a plan. The plans can be changed. The structure, you don't change frequently because it's the structure. It's the base." Participant 2 acknowledges the importance of technology for millennials, but regulates the use of technology in the workplace. "I don't restrict their phone use," said Participant 2. "We have areas for them to use the phone. And, we have areas for the smokers to smoke," Participant 2 added. Participant 4 also clarified, "But, at the same time, they have to know that, 'Okay, yeah. We're friendly, but I'm still your boss. And, you still have to respect me and do what I asked you to do."”

The answers of business leaders match that of Gilbert's (1978) BEM and the review of the professional literature. According to Gilbert (1978), the managers have the opportunity to observe their subordinates and ask important questions to determine how they can support their subordinates. Utilizing BEM, managers can check and improve organizational support factors such as "instruments" or the workers' ability to have the resources they need to do their jobs. In fact, Gilbert postulated that a worker's failure to meet work expectations can mean that the manager either showed incompetence or failed to define accomplishments and assign responsibilities.

Millennial employees enjoy having a close relationship with their superiors (Meola, 2016; Ferri-Reed, 2014a). In fact, millennial employees respond better to superiors seen as leaders rather than those who are domineering or micromanaging (Rather, 2018). Millennial workers prefer inspiring leaders over managers-leaders who could encourage them to participate in decision-making activities, and leaders who could inculcate meaning in their millennial employees' 
work (Seheult, 2016). Since there is a disparity on millennial behaviors and values compared to their older peers, it is important for business leaders to bridge that gap and create a close relationship with their millennial workers (Hall, 2016). Business leaders can use their position and influence to help their millennial workers by establishing a respectful, trusting, and supportive relationship. It is also important for business leaders to be aware of their millennial workers' well-being, to be able to help when needed, and being responsive to the needs of their millennial employees. A positive leader-member relationship between business leaders and millennial employees can help millennial workers maintain motivation in their jobs.

\subsection{Professional Development}

The small business leaders revealed that since millennials work in a stressful environment, it is important to implement professional and skills development efforts. Participant 1 described, "Restaurant business is very stressful. So, that's the number one thing you have to start dealing with is the level of stress, so a lot of employees have to understand that." Participant 3 explained, "Just like the millennials, their learning styles are different. Just like the managers' managing style and teaching style is different." Participant 3 added, "I mean, this job's not for everybody, just like every other job's not for every single person." Three subthemes emerged in the data analysis under the node "Professional Development": 1) access to information/feedback, 2) training, and 3) skills improvement.

Access to information/feedback. Business leaders reported that access to information is essential for millennial employees working in a restaurant. Information gathering results in useful knowledge that millennial employees can use in their jobs. Participant 1 said, "one of the most important things to me is, number 1, information." Participant 1 explained, "information can help them understand different risks such as cross-contamination or salmonella prevention." Providing work feedback gives the business leaders a chance to correct mistakes and improve employee performance. Participant 3 revealed:

"When they're doing something that's not right, instead of scolding them per se, I just go over, and I tweak it, or I teach them how to do it correctly. And, some people don't learn the same way as other people, so sometimes I'll have to correct them in different ways depending on their learning style."

Participant 3 explained that as millennial employees learn their duties and responsibilities, they are bound to make mistakes. It is important for business leaders to show patience in correcting their millennial employees. Moreover, business leaders must allow learning to occur and understand that different people learn differently.

Participant 4 explained that when employees come from different stores, they usually do not follow procedures done at their new store. "But, the new people, they take it very well. They catch on pretty quick. And, they ask questions," Participant 4 added. Feedback opportunity is useful to Participant 4 by pulling aside 
their millennial employees who do not do well. "Try to figure out what the problem is. And, see if we can just fix the problem, and move on, and make it work," Participant 4 explained.

The feedback mechanism also works for Participant 3 even to those millennial employees who feel entitled. Participant 3 further added, "Because I explain, 'If so and so's not doing their job and you would have to pick up the slack, how would you feel about it?" Participant 3 noted that millennial employees "look at it from the other point of view, and it most of the time seems to work."

Training. While the business leaders disclosed that training is part of their motivational strategies towards millennial employees, each restaurant offered a different type of training. Participant 1 highlighted that family-owned restaurants are different from chain restaurants. "It's different because this is a family-owned restaurant. So, compared to a chain or corporate restaurant, it's completely different," Participant 1 explained. According to Participant 1, the owners of their restaurant get themselves involved in training employees. "We have the owners directly, so you pretty much know what's going on and it's very small. So, it's really easy to do that to train people and keep people organized and stuff like that," Participant 1 further stated.

Participant 2 noted, "We, basically, train on the basic overall customer service, customer awareness, core values." However, these, according to Participant 2, are self-explanatory. "But, the add-ons is where I can tell who's going above and beyond," Participant 2 added. Participant 4 indicated online training available to all employees. "We have I TRAINs online that we have to do. It's pretty much videos that give you a step-by-step breakdown on different ways you can handle different situations, and learn how to teach people, train people a certain way," explained Participant 4.

Skills improvement. As part of training, business leaders divulged that skills improvement helps millennial employees overcome personality problems at work. Participant 1 offers stress management to their millennial employees. "By keeping calm, number one. A lot of jobs require a level of stress. So, if you know that it's already stressful and you're dealing with that every day then that's called experience," Participant 1 stated. Finding new things to improve daily is another strategy that works for Participant 1:

"If we start accomplishing small tasks, real tiny, tiny, tiny things, then we start feeling secure about accomplishing bigger tasks. So, you go from accomplishing something small. And, if you have those things that you do the same thing over and over, then it becomes easier and easier because you start getting experience, and you're performing, and your skills get stronger because you're constantly improving skills."

Participant 1 believes in second chances and the importance of harnessing skills by doing things repetitively. As millennial employees become comfortable doing the same things, they also gain experience as well as confidence. For Participant 1 , constant improvement of skills is necessary for a restaurant business. 
Participant 2 reported that ineffective time management and not wanting to take responsibility have a negative influence on millennial employees' performance. "The biggest thing is effective time, using their time effectively," explained Participant 2. "You have all types of challenges from being lazy to being late to not wanting to take responsibilities," Participant 2 added. Participant 2 solved these challenges through the incentive program.

Participant 3 agreed with Participant 2, "A lot of them feel very entitled... That was my biggest key challenge that I had to overcome and figure out how to work around." Participant 4 had the same sentiment, "Their attitudes and the way they handle each new situation... as far as learning a new product or dealing with a disgruntled customer. Just the way they handle them." Participant 4 overcame these challenges by providing skills improvement to their millennial employees. "We teach them to assess the situation, ask questions, try to see if they can fix it. What can they do to fix it?" And, if millennial employees solved the issues, Participant 4 reminded to compliment them, "Give them a smile." Tell them, 'Thank you.'”

The business leaders, through their responses, confirmed Gilbert's (1978) BEM and the review of the professional literature. Gilbert argued that managers should first determine issues or concerns with environmental (organizational) supports beginning with data or information. According to Gilbert, to increase employee competence managers must provide feedback on how their employees are doing, set clear work expectations, and give guidance on how to perform well. Binder (1998) also placed expectations and feedback as a priority in his Six Boxes Approach—a revision to Gilbert's (1978) BEM. The manager has an important role to play in ensuring employees are performing well.

Access to information and development opportunities are important to millennial employees. Millennial workers enjoy open communication with their superiors and the ability to share information with their colleagues (Hall, 2016). Rather (2018) explained that millennial employees move from one job to another because they continuously seek immediate growth opportunities, that is why they always want feedback from their team leaders. Seheult (2016) agreed that millennial workers value feedback and affirmation from their leaders whom they could consider as their mentors. Meola (2016) suggested that business leaders should help their millennial employees improve their soft skills through training and skills enhancement. According to Jones et al. (2018), millennial employees believe in setting goals and working hard to realize their dreams, that is why they value mentoring and training from their leaders. Millennial workers consider training as an essential aspect of their work (Holden \& Moser, 2016). Millennial workers will likely show loyalty to their jobs when given a chance to improve and expand on their skills (Boysen et al., 2016). Business leaders can keep their millennial employees motivated by helping them grow professionally. Even though millennials have distinct traits and attributes compared to the older generations, business leaders tailor their leadership style to meet the needs of their 
millennial employees, provide support, and help their millennial employees achieve their highest potentials.

\section{Applications to Professional Practice}

The study findings revealed rewards and recognition, high-quality leader-member relationship, and professional development as the top strategies that small business leaders use in motivating their millennial workforce. Since more than $73.5 \%$ of business leaders show concern in keeping their millennial employees motivated (Ferri-Reed, 2014a), it is vital for business leaders to learn more about their millennial employees. Business leaders can alleviate their frustrations, concerns, criticisms, and cynicism towards their millennial employees by understanding that negative stereotypes surrounding millennials are not helpful in business practices. Weeks et al. (2017) warned that negative stereotypes towards any generational cohort have negative consequences on the way people relate with each other. More specifically, Weeks et al. discussed that if people think millennials are lazy, they might treat millennials as untrustworthy, and lack of trust in an organization can often lead to lower productivity. If business leaders see younger workers as less desirable due to negative stereotypes, the business leaders might withhold career growth opportunities, increased responsibilities, and other benefits which can become discriminatory practices (Marchiondo et al., 2016). Negative stereotypes are not only detrimental to workplace relationships but hinder growth and development which are valuable to millennial employees. Business leaders, therefore, can look at the positive traits of their millennial employees and use those qualities to benefit their organizations.

Business leaders can use Gilbert's (1978) BEM to help improve their millennial employees' performance. Following Gilbert's (1978) BEM, business leaders can improve organizational support tools to help their millennial employees become successful in their positions. Business leaders can check if millennial employees are receiving enough information (data) and guidance on how they perform based on organizational expectations. Also, business leaders can provide tools and resources (instruments) so that millennial employees can do their jobs more effectively. Moreover, business leaders can ensure motivational strategies (incentives) are in place to enable millennial employees to perform exceptionally.

Business leaders can also learn from the findings of this study and adopt in their business strategies. Business leaders can improve their relationships with their millennial employees by becoming mentors instead of bosses. Millennial employees are more likely to become committed and engaged in their organizations if their superiors build trust, allow them to grow, and act as mentors rather than managers (Seheult, 2016). Savino (2017) encouraged team leaders to foster collaboration and a sense of belongingness for teams that include millennial members. Access to information, constant communication, and compliments 
are effective ways to create a family-like atmosphere (Savino, 2017). It is also crucial for business leaders to consider implementing rewards and recognition programs tailored to the needs of their millennial employees. According to Jauhar et al. (2017), team leaders who offer financial rewards and bonuses, recognition, and genuine appreciation of their millennial employees help their employees become satisfied in their jobs and have less intention to quit. By being generous in praises, offering rewards and incentives for meeting goals, and recognizing good work, business leaders can motivate their millennial employees and help improve performance.

\section{Implications for Social Change}

The assumption of millennials to the majority of employment occupations worldwide poses significant concerns for business leaders and organizations. Millennials bring with them their distinct traits, behaviors, and values into their workplace. Organizations may not be ready to cater to the needs of their millennial workforce. The management strategies used towards the older generation may not necessarily work towards millennial employees. Meola (2016) explained that some challenges business leaders have included their ability to build relationships with their millennial employees and their understanding of their millennial employees' work motivation. Millennials also face many challenges, and without any solutions in place, there may be a grim prospect for millennials' future (Accius \& Yeh, 2017). Accius and Yeh (2017) further contended that as millennials enjoy improved life experiences in their younger years, they will have a greater chance at financial security, healthy well-being, and contentment in their older years-benefitting their societies in general. Also, Rather (2018) pointed out that millennial workers will become the leaders of their organizations in the future, that is why organizations need to invest time and resources to their millennial employees. Helping millennial employees become successful has positive effects in securing the future of organizations and societies.

Organizations and business leaders also need to understand the work values and preferences of millennials. Researchers have pointed out that millennials value leisure more than work; therefore, it is necessary for organizations to implement a more balanced work-life program (Ertas, 2015; Woods, 2016). Millennial workers tend to move from one job to another in search for career growth and sense of meaning (Bushardt et al., 2018; Ferri-Reed, 2014c; Meola, 2016). Supporting the work values of employees may influence job satisfaction and the employees' tendency to remain in their jobs longer (Hammer, 2015; Kuron et al., 2015). As millennial workers become motivated in their careers, they are less likely to look for employment elsewhere. They will have a chance to grow in their positions, become more stable financially, and earn sufficient experience to lead their companies as future leaders. Preventing costly employee turnover and having highly productive workers may result in increased profitability for businesses. In turn, companies may become contributors to the development of the 
communities they serve. Likewise, healthy, career-oriented, and financially-stable millennials can become social change agents.

\section{Recommendations for Action}

Business leaders and owners of small business restaurants should consider if the strategies revealed in this study align with their current strategy to motivate their millennial workforce. Based on the results of this study, there are three recommendations that can help business leaders and owners of small business restaurants in executing their motivational strategies. First, build a high-quality, trusting, respectful, and supportive relationship with millennial employees. Business leaders are in a position to develop a bridge between millennial employees and the leadership team (Desy et al., 2017). Business leaders can change their management style to fit the needs of their millennial employees and help narrow the gap with older generations to create a more efficient organization (Lewis \& Wescott, 2017). When team leaders and millennial employees establish a healthy relationship, there will be more open communication. Business leaders can inspire their millennial employees to carry out their business strategies. In return, millennial employees can feel at ease communicating their needs to their team leaders.

Second, business leaders and owners of small business restaurants should incorporate leadership training programs in their curriculum that deals with the management and leadership of millennial workers. Corporate training programs on how to work with millennials such as discussion on various leadership models have become a necessity for companies (Meola, 2016). Desy et al. (2017) recommended employee training programs focused on teamwork and collaboration as well as utilization of technology because these are effective in millennials' learning style. Understanding and learning more about the preferences, values, and behaviors of millennials can help business leaders implement appropriate organizational practices. These practices may include providing constant feedback, career advancement, and leadership opportunities for millennial employees (Meng et al., 2017). Through information and training programs, business leaders can eliminate negative stereotypes towards millennials, and help promote a more positive approach to dealing with their millennial employees.

Third, organizations must integrate a rewards system into their business strategies so that millennial employees can earn incentives as they help accomplish objectives. Organizations must revisit their practices including evaluation and rewards system as they cater to the needs of their millennial employees (Campione, 2015). Millennial employees value rewards at work such as higher salaries and position (Rather, 2018). Millennials desire rewards and incentives as well as immediate feedback, career advancement, and pay increases (Anderson et al., 2016). Business leaders can create individual and organizational goals and encourage participation from their millennial employees, giving them a chance to earn rewards as they meet those goals. 


\section{Recommendations for Further Research}

Research limitations are systematic biases that a researcher could not control and may have an impact on the outcome of the study (Price, 2004). Limitations in research are normal because of the improbability to conduct a limitations-free study, and by including limitations in a research study, other researchers get a chance to take the study further (Singh, 2015). There were two limitations in this study. First, since the participants were small business leaders from restaurant businesses located in eastern North Carolina who have successfully led and motivated a millennial workforce, the motivational strategies directed specifically towards the millennial workers may not be as effective towards the older workers. The second limitation was that the results of this study may pertain only to small businesses, particularly in the restaurant sector, and may not be relevant to other businesses in eastern North Carolina.

The results from this study warrant further investigation of strategies that small business leaders use to motivate their millennial employees from other researchers. It is recommended the exploration of motivational strategies in a multi-generational workforce that includes baby boomers and generation $\mathrm{X}$ workers. Soon, other researchers may also include generation $\mathrm{Z}$ workers in the study. Second, since this study pertains only to small businesses in the restaurant sector, it is recommended that further studies expand the industry scope and investigate motivational strategies of other business leaders such as those in retail, service, communications, and entertainment industries. Third, it is recommended that other researchers replicate or expand this study in demographic areas outside of eastern North Carolina. Fourth, it is suggested that future research includes a larger sample size to enhance the reliability and validity of findings.

\section{Conclusion}

Millennials are occupying the majority of the global workforce, and business leaders show concerns in training and motivating their millennial employees. A qualitative, multiple case study was used to explore the strategies that business leaders use to motivate their millennial employees. Four business leaders from four restaurants in eastern North Carolina participated in this research. Semistructured, face-to-face interviews with seven open-ended questions were used as well as a review of company records to include company websites and social media. A methodological triangulation of data sources and thematic analysis of data revealed strategies business leaders use to motivate their millennial employees.

First, business leaders reported that rewards and recognition are prime motivators for their millennial employees. Business leaders use verbal compliments and written reviews as a way to appreciate their millennial employees as well as incentives as rewards for meeting goals. Second, business leaders develop a 
high-quality leader-member relationship as a motivational strategy towards their millennial employees. Millennials who do not do well with authority benefit from respectful, trusting, and supportive team leaders who listen to their concerns and help them resolve their issues while maintaining the right balance in the relationship. Third, business leaders disclosed professional development as another strategy in motivating their millennial employees. Business leaders provide information and feedback on their millennial workers' performance, offer training to enhance work knowledge as well as opportunities to improve on skills such as interpersonal and problem-solving skills.

With the changing demography of the global employment landscape, business leaders must find ways to innovate their leadership strategies to meet the emergent needs of their workers. The findings in this research study contribute to practical solutions to leading the largest generation in today's workforce-the millennials. The successful utilization of these strategies can help keep millennial workers motivated in their jobs. When employees are motivated to work, they remain committed in their careers, and organizations become highly productive and profitable. Healthy organizations and profitable small businesses will continue to be the backbone of the U.S. economy bringing in government revenues through taxes while the citizens continue to be employed.

\section{Conflicts of Interest}

The author declares no conflicts of interest regarding the publication of this paper.

\section{References}

Accius, J., \& Yeh, J. C. (2017). America Must Invest in Its Next Generations. Generations, 40, 101-107. http://www.asaging.org

Alase, A. (2017). The Interpretative Phenomenological Analysis (IPA): A Guide to a Good Qualitative Research Approach. International Journal of Education \& Literacy Studies, 5, 9-19. https://doi.org/10.7575/aiac.ijels.v.5n.2p.9

Anderson, C. (2010). Presenting and Evaluating Qualitative Research. American Journal of Pharmaceutical Education, 74, 141. https://doi.org/10.5688/aj7408141

Anderson, E., Buchko, A. A., \& Buchko, K. J. (2016). Giving Negative Feedback to Millennials. How Can Managers Criticize the "Most Praised" Generation. Management Research Review, 39, 692-705. https://doi.org/10.1108/MRR-05-2015-0118

Ang, C. K., Embi, M. A., \& Yunus, M. M. (2016). Enhancing the Quality of Findings on a Longitudinal Case Study: Reviewing Trustworthiness via ATLAS.ti. The Qualitative Report, 21, 1855-1867. https://nsuworks.nova.edu/tqr/

Anggraeni, A. I., Dwiatmadja, C., \& Yuniawan, A. (2017). The Role of Psychological Contract on Employee Commitment and Organisational Citizenship Behaviour: A Study of Indonesian Young Entrepreneurs in Management Action. SA Journal of Industrial Psychology, 43, a1409. https://doi.org/10.4102/sajip.v43i0.1409

Aruna, M., \& Anitha, J. (2015). Employee Retention Enablers: Generation Y Employees. SCMS Journal of Indian Management, 12, 94-103. http://www.scms.edu.in 
Asiamah, N., Mensah, H. K., \& Oteng-Abayie, E. F. (2017). General, Target, and Accessible Population: Demystifying the Concepts for Effective Sampling. The Qualitative Report, 22, 1607-1622. https://nsuworks.nova.edu/tqr/

Belcher, M. (2015). The Rise of the Young Professionals. Professional Safety, 60, 8. http://www.asse.org

Benoot, C., Hannes, K., \& Bilsen, J. (2016). The Use of Purposeful Sampling in a Qualitative Evidence Synthesis: A Worked Example on Sexual Adjustment to a Cancer Trajectory. BMC Medical Research Methodology, 16, Article No. 21. https://doi.org/10.1186/s12874-016-0114-6

Berry, L. E. (2016). The Research Relationship in Narrative Enquiry. Nurse Researcher, 24, 10-14. https://doi.org/10.7748/nr.2016.e1430

Binder, C. (1998). The Six Boxes ${ }^{\mathrm{Tx}}$ : A Descendant of Gilbert's Behavior Engineering Model. Performance Improvement, 37, 48-52. https://doi.org/10.1002/pfi.4140370612

Boswell, J. N., Wilson, A. D., Stark, M. D., \& Onwuegbuzie, A. J. (2015). The Role of Mentoring Relationships in Counseling Programs. International Journal of Mentoring and Coaching in Education, 4, 168-183. https://doi.org/10.1108/IJMCE-03-2015-0007

Boysen, P. G., Daste, L., \& Northern, T. (2016). Multigenerational Challenges and the Future of Graduate Medical Education. The Ochsner Journal, 16, 101-107. http://ochsnerjournal.org

Bushardt, S. C., Young, M., \& Bari, A. (2018). Transitioning to Management: Challenges and Opportunities for the Millennial Generation. The Journal of Business Diversity, 18, 9-16. http://www.na-businesspress.com https://doi.org/10.33423/jbd.v18i1.514

Buzdar, M. A., Waqas, M., Mohsin, M. N., \& Nadeem, M. (2016). Relationship between Social Intelligence and Religious Orientations of University Students. Journal of Educational Research, 19, 1-9. http://iub.edu.pk

Campione, W. A. (2015). Corporate Offerings: Why Aren't Millennials Staying? Journal of Applied Business and Economics, 17, 60-75. http://www.na-businesspress.com

Campione, W. A. (2016). Volunteer Work Experience: Can It Help Millennials to Find Meaning and Interest in Their Work and to Negotiate Their Role within the Workplace? Journal of Leadership, Accountability and Ethics, 13, 11-27. http://www.na-businesspress.com

Carballo, O. C., \& Badilla, D. C. (2014). EFL/ESL Freshman Students at UNA: The Case of the Millennials. Revista de Lenguas Modernas, 21, 369-383. http://revistas.ucr.ac.cr

Castillo-Montoya, M. (2016). Preparing for Interview Research: The Interview Protocol Refinement Framework. The Qualitative Report, 21, 811-830. https://nsuworks.nova.edu/tqr/

Catano, V. M., \& Hines, H. M. (2016). The Influence of Corporate Social Responsibility, Psychologically Healthy Workplaces, and Individual Values in Attracting Millennial Job Applicants. Canadian Journal of Behavioural Science, 48, 142-154. https://doi.org/10.1037/cbs0000036

Chen, J., \& Lian, R. (2015). Generational Differences in Work Values in China. Social Behavior and Personality, 43, 567-578. https://doi.org/10.2224/sbp.2015.43.4.567

Cho, J. Y., \& Lee, E. (2014). Reducing Confusion about Grounded Theory and Qualitative Content Analysis: Similarities and Differences. The Qualitative Report, 19, 1-20. https://nsuworks.nova.edu/tqr/

Cho, Y. J., \& Song, H. J. (2017). Determinants of Turnover Intention of Social Workers: 
Effects of Emotional Labor and Organizational Trust. Public Personnel Management, 46, 41-65. https://doi.org/10.1177/0091026017696395

Costanza, D. P., \& Finkelstein, L. M. (2015). Generationally Based Differences in the Workplace: Is There a There There? Industrial and Organizational Psychology, 8, 308-323. https://doi.org/10.1017/iop.2015.15

Cox, J. H., Frank, B., \& Philibert, N. (2006). Valuing the Gilbert Model: An Exploratory Study. Performance Improvement Quarterly, 19, 23-41. https://doi.org/10.1111/j.1937-8327.2006.tb00744.x

Dean, P. J. (2016). Tom Gilbert: Engineering Performance with or without Training. Performance Improvement, 55, 30-38. https://doi.org/10.1002/pfi.21556

Deery, M., \& Jago, L. (2015). Revisiting Talent Management, Work-Like Balance and Retention Strategies. International Journal of Contemporary Hospital Management, 27, 453-472. https://doi.org/10.1108/IJCHM-12-2013-0538

Desy, J. R., Reed, D. A., \& Wolanskyj, A. P. (2017). Milestones and Millennials: A Perfect Pairing-Competency-Based Medical Education and the Learning Preferences of Generation Y. Mayo Clinic Proceedings, 92, 243-250.

https://doi.org/10.1016/j.mayocp.2016.10.026

Dimitriou, C. K., \& Blum, S. C. (2015). An Exploratory Study of Greek Millennials in the Hotel Industry: How Do They Compare to Other Generations? International Journal of Global Business, 8, 62-92. https://gsmi-ijgb.com/?page id=75

Earle, A. M., \& LaBrie, J. W. (2016). The Upside of Helicopter Parenting: Engaging Parents to Reduce First-Year Student Drinking. Journal of Student Affairs Research and Practice, 53, 319-330. https://doi.org/10.1080/19496591.2016.1165108

Ertas, N. (2015). Turnover Intentions and Work Motivations of Millennial Employees in Federal Service. Public Personnel Management, 44, 401-423. https://doi.org/10.1177/0091026015588193

Ferri-Reed, J. (2014a). Are Millennial Employees Changing How Managers Manage? The Journal for Quality and Participation, 37, 15-18, 35. http://www.asq.org

Ferri-Reed, J. (2014b). Building Innovative Multi-Generational Teams. Journal for Quality and Participation, 37, 20-22. http://www.asq.org

Ferri-Reed, J. (2014c). “Millennializing” Your Work Culture. The Journal for Quality and Participation, 37, 21-24. http://www.asq.org

Fork, R. M. H., \& Yeung, R. M. W. (2016). Work Attitudes of Generation Y in Macau's Hotel Industry: Management's Perspective. Worldwide Hospitality and Tourism Themes, 8, 83-96. https://doi.org/10.1108/WHATT-10-2015-0034

Fortin, C., \& Hennessy, K. (2015). The Appropriation of a Digitally-Augmented Agora: Field Study of the Structuration and Spatialization of an Issue Public in Urban Space. Canadian Journal of Communication, 40, 675-693. http://www.cjc-online.ca https://doi.org/10.22230/cjc.2015v40n4a2926

Fusch, P. I., \& Ness, L. R. (2015). Are We There Yet? Data Saturation in Qualitative Research. The Qualitative Report, 20, 1408-1416. https://nsuworks.nova.edu/tqr/

Gentles, S. J., Charles, C., Ploeg, J., \& McKibbon, K. A. (2015). Sampling in Qualitative Research: Insights from an Overview of the Methods Literature. The Qualitative Report, 20, 1772-1789. https://nsuworks.nova.edu/tqr/

George, J., \& Wallio, S. (2017). Organizational Justice and Millennial Turnover in Public Accounting. Employee Relations, 39, 112-126.

https://doi.org/10.1108/ER-11-2015-0208 
Gilbert, T. F. (1978). Human Competence-Engineering Worthy Performance. NSPI Journal, 17, 19-27. https://doi.org/10.1002/pfi.4180170915

Gilley, A., Waddell, K., Hall, A., Jackson, S. A., \& Gilley, J. W. (2015). Manager Behavior, Generation, and Influence on Work-Life Balance: An Empirical Investigation. The Journal of Applied Management and Entrepreneurship, 20, 3-23.

https://browzine.com/libraries/2161/journals/246554/issues/current

Gov, O. (2015). The Complex Relationship between Intrinsic and Extrinsic Rewards. Economics and Business Review, 1, 102-125. https://doi.org/10.18559/ebr.2015.4.7

Hadi, M. A., \& Closs, S. J. (2016). Ensuring Rigour and Trustworthiness of Qualitative Research in Clinical Pharmacy. International Journal of Clinical Pharmacy, 38, 641-646. https://doi.org/10.1007/s11096-015-0237-6

Hall, A. (2016). Exploring the Workplace Communication Preferences of Millennials. Journal of Organizational Culture, Communications and Conflict, 20, 35-44. http://www.alliedacademies.org

Hammer, E. E. (2015). Shifts in Calling: An Emphasis on Calling for Millennials. American Journal of Management, 15, 22-25. http://www.na-businesspress.com

Hancock, M. E., Amankwaa, L., Revell, M. A., \& Mueller, D. (2016). Focus Group Data Saturation: A New Approach to Data Analysis. The Qualitative Report, 21, 2124-2130. https://nsuworks.nova.edu/tqr/

Harif, M. A. A. M., \& Hoe, M. K. A. (2018). Critical Success Determinants of Client-Server Hardware System Adoption: Malaysian SME Business Context. Review of Integrative Business and Economics, 7, 65-80. http://buscompress.com

Henstra, D., \& McGowan, R. A. (2016). Millennials and Public Service: An Exploratory Analysis of Graduate Student Career Motivators and Expectations. Public Administration Quarterly, 40, 490-516. https://paq.spaef.org

Hewitt, M. B. (2015). Let's Talk about It: Helping Students Explore Their Feelings. Reclaiming Children and Youth, 24, 16-19. http://reclaimingjournal.com

Holden, C., \& Moser, A. (2016). Survival Guide for Clinical Engineering Millennials. Biomedical Instrumentation \& Technology, 50, 422-426. http://www.aami-bit.org https://doi.org/10.2345/0899-8205-50.6.422

Houghton, C., Murphy, K., Shaw, D., \& Casey, D. (2015). Qualitative Case Study Data Analysis: An Example from Practice. Nurse Researcher, 22, 8-12.

https://journals.rcni.com https://doi.org/10.7748/nr.22.5.8.e1307

Jauhar, J., Ting, C. S., \& Rahim, N. F. A. (2017). The Impact of Reward and Transformational Leadership on the Intention to Quit of Generation Y Employees in Oil and Gas Industry: Moderating Role of Job Satisfaction. Global Business and Management Research: An International Journal, 9, 426-441. http://www.gbmrjournal.com/

Jiang, X., \& Yang, H. (2016). Impacts of Optimism and Job Characteristics on Job Burnout among the Millennial Generation: Evidence from a Survey of Community Service Workers in Shaanxi, China. Revista de Cercetare si Interventie Sociala, 53, 185-212. http://www.rcis.ro

Jones, A. (2015). Organisational Commitment in Nurses: Is It Dependent on Age or Education? Nursing Management, 21, 29-36. https://doi.org/10.7748/nm.21.9.29.e1298

Jones, J. S., Murray, S. R., \& Tapp, S. R. (2018). Generational Differences in the Workplace. Journal of Business Diversity, 18, 88-97. http://www.na-businesspress.com https://doi.org/10.33423/jbd.v18i2.528 
Kilber, J., Barclay, A., \& Ohmer, D. (2014). Seven Tips for Managing Generation Y. Journal of Management Policy and Practice, 15, 80-91. http://www.na-businesspress.com

Kuron, L. K. J., Lyons, S. T., Schweitzer, L., \& Ng, E. S. W. (2015). Millennials' Work Values: Differences across the School to Work Transition. Personnel Review, 44, 991-1009. https://doi.org/10.1108/PR-01-2014-0024

Kwon, K., Yoo, G., \& Binghan, G. E. (2016). Helicopter Parenting in Emerging Adulthood: Support or Barrier for Korean College Students' Psychological Adjustment? Journal of Child and Family Studies, 25, 136-145. https://doi.org/10.1007/s10826-015-0195-6

Lewis, L. F., \& Wescott, H. D. (2017). Multi-Generation Workforce: Four Generations United in Lean. Journal of Business Studies Quarterly, 8, 1-14. http://jbsq.org

Lin, Y., Li, Y., \& Hou, X. (2015). Utilitarian Orientation, Long-Term Orientation, and Performance: Evidence from Chinese Millennial-Generation Employees. Social Behavior and Personality, 43, 1463-1476. https://doi.org/10.2224/sbp.2015.43.9.1463

Manda, P. (2015). Preparing Our Housing Transition to a Post-Baby Boom World: Reflections on Japan's May 26, 2015 Vacant Housing Law. Cityscape: A Journal of Policy Development and Research, 17, 239-248. http://www.huduser.gov

Marchiondo, L. A., Gonzales, E., \& Ran, S. (2016). Development and Validation of the Workplace Age Discrimination Scale. Journal of Business and Psychology, 31, 493-513. https://doi.org/10.1007/s10869-015-9425-6

Martin, T. N., \& Ottemann, R. (2015). Generational Workforce Demographic Trends and Total Organizational Rewards Which Might Attract and Retain Different Generational Employees. Journal of Behavioral and Applied Management, 16, 91-115. https://jbam.scholasticahq.com

Maslow, A. H. (1943). A Theory of Human Motivation. Psychological Review, 50, 370-396. http://www.apa.org https://doi.org/10.1037/h0054346

Meng, J., Reber, B. H., \& Rogers, H. (2017). Managing Millennial Communication Professionals: Connecting Generation Attributes, Leadership Development, and Employee Engagement. Acta Prosperitatis, 8, 68-119. http://www.turiba.lv

Meola, C. C. (2016). Addressing the Needs of the Millennial Workforce through Equine Assisted Learning. Journal of Management Development, 35, 294-303.

https://doi.org/10.1108/JMD-08-2015-0110

Miles, M. B., \& Huberman, A. M. (1994). Qualitative Data Analysis: An Expanded Sourcebook (2nd ed.). Thousand Oaks, CA: SAGE Publications.

Morse, J. M. (1994). Critical Issues in Qualitative Research Methods. Thousand Oaks, CA: SAGE Publications.

Navarro, K. M., \& Malvaso, S. (2016). Millennial Student-Athletes and Career Development: Toward an Understanding of Academic, Athletic and Parental Spheres of Influence on Career Aspirations and Undergraduate Major Choices. College Student Affairs Journal, 34, 30-47. http://www.infoagepub.com https://doi.org/10.1353/csj.2016.0017

Ng, E. S. W., Gossett, C. W., \& Winter, R. (2016). Millennials and Public Service Renewal: Introduction on Millennials and Public Service Motivation (PSM). Public Administration Quarterly, 40, 412-428. https://paq.spaef.org

Njoroge, C. N., \& Yazdanifard, R. (2014). The Impact of Social and Emotional Intelligence on Employee Motivation in a Multigenerational Workplace. International Jour- 
nal of Information, Business and Management, 6, 163-170. http://ijibm.elitehall.com

Nolan, L. S. (2015). The Roar of Millennials: Retaining Top Talent in the Workplace. Journal of Leadership, Accountability and Ethics, 12, 69-75. http://www.na-businesspress.com

Orange, A. (2016). Encouraging Reflexive Practices in Doctoral Students through Research Journals. The Qualitative Report, 21, 2176-2190. https://nsuworks.nova.edu/tqr/

Orchowski, M. S. (2014). Are Hispanic Millennials Leading Their Generation? The Hispanic Outlook in Higher Education, 24, 13-14. http://www.hispanicoutlook.com/

Palinkas, L. A., Horwitz, S. M., Green, C. A., Wisdom, J. P., Duan, N., \& Hoagwood, K. (2015). Purposeful Sampling for Qualitative Data Collection and Analysis in Mixed Method Implementation Research. Administration and Policy in Mental Health and Mental Health Services Research, 42, 533-544. https://doi.org/10.1007/s10488-013-0528-y

Park, R. (2016). Autonomy and Citizenship Behavior: A Moderated Mediation Model. Journal of Managerial Psychology, 31, 280-295.

https://doi.org/10.1108/JMP-01-2014-0028

Pershing, J. A. (2016). Looking Back to Look Forward: Pathfinders No. 2. Gilbert: The Father of Human Performance Technology. Performance Improvement, 55, 27-29. https://doi.org/10.1002/pfi.21554

Phillips, C. R., \& Trainor, J. E. (2014). Millennial Students and the Flipped Classroom. Journal of Business and Educational Leadership, 5, 102-112. http://asbbs.org

Pinzaru, F., \& Mitan, A. (2016). Managers versus Digital Natives Employees. A Study Regarding the Perceptions of the Romanian Managers Working with Youngsters. Management Dynamics in the Knowledge Economy, 4, 153-166.

http://www.managementdynamics.ro

Pinzaru, F., Vatamanescu, E., Mitan, A., Savulescu, R., Vitelar, A. et al. (2016). Millennials at Work: Investigating the Specificity of Generation Y versus Other Generations. Management Dynamics in the Knowledge Economy, 4, 173-192.

http://www.managementdynamics.ro

Price, J. H. (2004). Research Limitations and the Necessity of Reporting Them. American Journal of Health Education, 35, 66-67. https://doi.org/10.1080/19325037.2004.10603611

Rather, B. A. (2018). Millennial Generation: Redefining People Policies for Changing Employment Trends. The Researchers' International Research Journal, 4, $27-41$.

Rickes, P. C. (2016). Generations in Flux: How Gen Z Will Continue to Transfer Higher Education Space. Planning for Higher Education Journal, 44, 21-45.

http://www.scup.org

Rimando, M., Brace, A., Namageyo-Funa, A., Parr, T. L., Sealy, D., Davis, T. L. et al. (2015). Data Collection Challenges and Recommendations for Early Career Researchers. The Qualitative Report, 20, 2025-2036. https://nsuworks.nova.edu/tqr/

Sanner-Stiehr, E., \& Vandermause, R. K. (2017). Can't We Just Get Along? A Dual-Theory Approach to Understanding and Managing the Multigenerational Workplace. Journal of Organizational Psychology, 17, 103-110. http://www.na-businesspress.com

Savino, E. M. (2017). Quick! How Do I Deal with a Multigenerational Workforce? Strategic HR Review, 16, 192-193. https://doi.org/10.1108/SHR-09-2016-0087

Segrin, C., Givertz, M., Swaitkowski, P., \& Montgomery, N. (2015). Overparenting Is Associated with Child Problems and a Critical Family Environment. Journal of Child and 
Family Studies, 24, 470-479. https://doi.org/10.1007/s10826-013-9858-3

Seheult, E. (2016). Generational Mentorship: What Millennial Mentees Want. College and University, 91, 39-42. https://www.aacrao.org

Simpson, A., \& Quigley, C. F. (2016). Member Checking Process with Adolescent Students: Not Just Reading a Transcript. The Qualitative Report, 21, 377-392.

https://nsuworks.nova.edu/tqr/

Singh, R. (2016). The Impact of Intrinsic and Extrinsic Motivators on Employee Engagement in Information Organizations. Journal of Education for Library and Information Science, 57, 197-206. https://doi.org/10.3138/jelis.57.2.197

Singh, S. (2015). Hello, Limitations! The Paradoxical Power of Limits in Scientific Writing. Indian Journal of Dermatology, Venereology and Leprology, 81, 4-6. https://doi.org/10.4103/0378-6323.148555

Smith, T. J., \& Nichols, T. (2015). Understanding the Millennial Generation. Journal of Business Diversity, 15, 39-47. http://www.na-businesspress.com

Stark, R., \& Farner, S. (2015). Intergenerational Warfare in the U.S. Workplace, or Nothing More than Growing Pains? S.A.M. Advanced Management Journal, 80, 4-11. http://www.uncfsu.edu

Tews, M. J., Michel, J., Xu, S., \& Drost, A. J. (2015). Workplace Fun Matters... but What Else? Employee Relations, 37, 248-267. https://doi.org/10.1108/ER-10-2013-0152

Thompson, C., \& Gregory, J. B. (2012). Managing Millennials: A Framework for Improving Attraction, Motivation and Retention. The Psychologist-Manager Journal, 15, 237-246. https://doi.org/10.1080/10887156.2012.730444

Tong, J., Wang, L., \& Peng, K. (2015). From Person-Environment Misfit to Job Burnout: Theoretical Extensions. Journal of Managerial Psychology, 30, 169-182.

https://doi.org/10.1108/JMP-12-2012-0404

Turner, D. W. (2010). Qualitative Interview Design: A Practical Guide for Novice Investigators. The Qualitative Report, 15, 754-760. https://nsuworks.nova.edu/tqr/

U.S. Census Bureau (2015). Millennials Outnumber Baby Boomers and Are Far More Diverse, Census Bureau Reports. https://www.census.gov

Van Rijnsoever, F. J. (2017). (I Can't Get No) Saturation: A Simulation and Guidelines for Same Sizes in Qualitative Research. PLoS ONE, 12, e0181689. https://doi.org/10.1371/journal.pone.0181689

Villena-Alvarez, J. (2016). Academia's Challenge: Training Faculty to Teach Millennials in the Digital Age. International Journal of Arts \& Sciences, 9, 373-384.

http://www.internationaljournal.org

Wadsworth, N. D. (2017). Awakening the "Walking Dead": Zombie Pedagogy for Millennials. Radical Teacher, No. 107, 4-13. https://doi.org/10.5195/rt.2017.260

Warland, J., McKellar, L., \& Diaz, M. (2014). Assertiveness Training for Undergraduate Midwifery Students. Nurse Education in Practice, 14, 752-756.

https://doi.org/10.1016/j.nepr.2014.09.006

Watroba, W. T. (2017). Cross-Generational Transgressions of Work Attitudes. International Journal of Arts \& Sciences, 9, 549-558. http://www.internationaljournal.org

Weeks, K. P., Weeks, M., \& Long, N. (2017). Generational Perceptions at Work: In-Group Favoritism and Out-Group Stereotypes. Equality, Diversity and Inclusion: An International Journal, 36, 33-53. https://doi.org/10.1108/EDI-07-2016-0062

Weirich, B. (2017). A Millennial Leader's Views on the Millennial Workforce. Nurse Leader, 15, 137-139. https://doi.org/10.1016/j.mnl.2016.12.003 
Wiedmer, T. (2015). Generations Do Differ: Best Practices in Leading Traditionalists, Boomers, and Generations X, Y, and Z. Delta Kappa Gamma Bulletin, 82, 51-58.

https://www.dkg.org

Willgens, A. M., Cooper, R., Jadotte, D., Lilyea, B., Langtiw, C., \& Obenchain-Leeson, A. (2016). How to Enhance Qualitative Research Appraisal: Development of the Methodical Congruence Instrument. The Qualitative Report, 21, 2380-2395. https://nsuworks.nova.edu/tqr/

Wilson, A. D., Onwuegbuzie, A. J., \& Manning, L. P. (2016). Using Paired Depth Interviews to Collect Qualitative Data. The Qualitative Report, 21, 1549-1573. https://nsuworks.nova.edu/tqr/

Winiecki, D. J. (2015). Comparing a Few Behavior Engineering Models. Performance Improvement, 54, 6-14. https://doi.org/10.1002/pfi.21501

Woods, K. (2016). Organizational Ambidexterity and the Multi-Generational Workforce. Journal of Organizational Culture, Communications and Conflict, 21, 95-111. http://www.abacademies.org

Xie, B., Xin, X., \& Bai, G. (2016). Hierarchical Plateau and Turnover Intention of Employees at the Career Establishment Stage: Examining Mediation and Moderation Effects. Career Development International, 21, 518-533.

https://doi.org/10.1108/CDI-04-2015-0063

Yin, R. K. (2014). Case Study Research: Design and Methods (5th ed.). Thousand Oaks, CA: SAGE Publications. 